\title{
The role of business analytics capabilities in bolstering firms' agility and performance
}

\author{
Amir Ashrafi ${ }^{\mathrm{a}}$, Ahad Zare Ravasan ${ }^{\mathrm{b}}$, Peter $\operatorname{Trkman}^{\mathrm{c}, *}$, Samira Afshari ${ }^{\mathrm{a}}$ \\ a Allameh Tabataba'i University, Tehran, Iran \\ ${ }^{\mathrm{b}}$ Masaryk University, Brno, Czech Republic \\ ${ }^{\mathrm{c}}$ University of Ljubljana, Slovenia
}

\section{A R T I C L E I N F O}

\section{Keywords:}

Business analytics

Agility

Information quality

Innovative capability

Environmental turbulence

Partial least squares

\begin{abstract}
A B S T R A C T
Many companies invest considerable resources in developing Business Analytics (BA) capabilities to improve their performance. BA can affect performance in many different ways. This paper analyses how BA capabilities affect firms' agility through information quality and innovative capability. Furthermore, it studies the moderating role of environmental turbulence, both technological and in the market. The proposed model was tested using statistical data from 154 firms with two respondents (CEO and CIO) from each firm. The data were analysed using Partial Least Squares (PLS)/Structured Equation Modelling (SEM). Our results indicate that BA capabilities strongly impact a firm's agility through an increase in information quality and innovative capability. We also discuss that both market and technological turbulence moderate the influence of firms' agility on firms' performance.
\end{abstract}

\section{Introduction}

Business analytics (BA) are overhauling the way firms are generating and using data (Ramanathan, Philpott, Duan, \& Cao, 2017). They attracted increasing attention from both academics and practitioners for their high operational and strategic potential across various industries, including financial services, insurance, retail, healthcare and manufacturing (Dubey, Gunasekaran, Childe, Wamba, \& Papadopoulos, 2016; Fosso Wamba, Ngai, Riggins, \& Akter, 2017).

BA can be defined as a holistic approach to manage, process and analyse data, not only to create actionable insights (adapted from Fosso Wamba, Akter, Edwards, Chopin, and Gnanzou, (2015)) but also to enable organisations to predict changes based on market requirements and respond to them quickly (Iş1k, Jones, \& Sidorova, 2013). BA systems involve the use of capabilities and technologies to collect, transform, analyse and interpret data to support decision-making (Santiago Rivera \& Shanks, 2015). BA are known as 'competitive differentiators (Jeble et al., 2018),' and both professional press and academic research consistently demonstrate a positive relationship between BA and organisational performance (Ramakrishnan, Jones, \& Sidorova, 2012; Viaene \& Van den Bunder, 2011).

However, the way in which BA influence performance is not entirely clear and calls for further research (Abbasi, Sarker, \& Chiang, 2016; Côrte-Real, Oliveira, \& Ruivo, 2017; Gunasekaran et al., 2017). Earlier papers on this topic have established a generally positive impact on performance (Gupta \& George, 2016; Trkman, McCormack, De Oliveira, \& Ladeira, 2010), investigated the availability, quality, and use of information (Popovič, Hackney, Coelho, \& Jaklič, 2012) or presented the benefits stemming therefrom (Wang, Kung, \& Byrd, 2018) without investigating the path of influence. Thus, while there is substantial evidence that investments in business analytics can create value, the way in which BA lead to value needs deeper analysis (Sharma, Mithas, \& Kankanhalli, 2014). In recent years, several attempts have been made to address this issue; Akter, Fosso Wamba, Gunasekaran, Dubey, and Childe, (2016) proposed a three-tier model to investigate the impact of big data analytics on firm performance by taking the moderating role of strategic alignment into account.

Ji-fan Ren, Fosso Wamba, Akter, Dubey, and Childe, (2017) showed that both system and information quality are principal factors in enhancing business value and firm performance. Their research used a resource-based view and information systems success to show that business value stems from the BA system, and information quality mediates the relationship between big data environment and firm performance. Fosso Wamba, Gunasekaran et al. (2017) proposed a conceptual model to explore the direct relationship between big data capabilities and firm performance, as well as the mediating effect of process-oriented dynamic capabilities. Torres, Sidorova, and Jones, (2018) used a dynamic capabilities perspective to determine the role of

\footnotetext{
* Corresponding author at: Department for Information and Logistics Management, University of Ljubljana, Faculty of Economics, SI-1000, Ljubljana, Slovenia.

E-mail address: peter.trkman@ef.uni-lj.si (P. Trkman).
} 
BA capabilities in improving firm performance.

It is clear that several interconnected issues influence whether enhanced BA capabilities influence a firm's performance (Dubey, Gunasekaran et al., 2018; Holsapple, Lee-Post, \& Pakath, 2014). We argue that while BA can impact the quality of information in an organisation, innovation capability (the ability of an organisation to perform innovative practices) is equally important (Wang, Dou, Zhu, \& Zhou, 2015). Both then improve the firm's agility specified as the ability to sense and react to opportunities and threats with ease, speed and dexterity (Tallon \& Pinsonneault, 2011).

Still, the firm's agility is not a final objective in itself so much as the required means for achieving and preserving a competitive advantage in a turbulent market (Sherehiy, Karwowski, \& Layer, 2007). We thus need to further examine the relationship between agility and firm performance under the moderating effect of technological (Trkman \& McCormack, 2009) and market turbulence (Jaworski \& Kohli, 1993). An interesting question remains as to whether and to what extent market and technological turbulence moderate the relationship between BA-enabled firm agility and firm performance.

The purpose of the present study is to better understand the influence of BA capabilities on firm agility and performance in the presence of environmental turbulence. Specifically, our research model seeks to address the following research questions:

RQ1- How does BA contribute to firm agility and performance?

RQ2- How does environmental turbulence influence the link between firm agility and performance?

To answer these questions, we propose a conceptual model to investigate the impact of BA on firm agility and performance by exploring the quality of information and innovation capability. We also follow this direction to find out the extent in which environmental turbulence moderates the link between firm agility and performance. We use a survey of 154 companies using Partial Least Squares (PLS)/Structured Equation Modelling (SEM) with two respondents from each organisation, and focus on a wide section of industries to validate the model in the context of a developing country.

The rest of the paper is arranged as follows: the conceptual framework is presented, followed by the related hypotheses and the research model. The methodology is discussed in Section 4, while Section 5 is the data analysis and results. Finally, discussion, implications and future research are presented in Section 6.

\section{Conceptual framework}

As Rivard (2014) stated, researchers should carefully take into account the proper construct definition and provide a clear conceptual definition for their proposed research constructs. Indeed, a lack of clear definition can harm the original meanings of constructs and increase the risk of ending up with as many meanings as there are readers (Rivard, 2014). Hence, the conceptual framework of the present study begins with a definition of each construct and related issues.

\subsection{The influence of $B A$ capability on performance}

There is no clear consensus on different terminologies related to BA (Arunachalam, Kumar, \& Kawalek, 2018), with Seddon, Constantinidis, Tamm, and Dod, (2017) listing no fewer than 18 different definitions of BA. Several authors even mix the terms 'big data' and 'analytics' (Roden, Nucciarelli, Li, \& Graham, 2017). For our purpose BA can be broadly described as an application of 'various techniques, technologies, systems, practices, methodologies, and applications that analyse critical business data' (Chen, Chiang, \& Storey, 2012; Ramanathan et al., 2017) to enable evidence-based problem-solving and recognition within the context of business situations (Holsapple et al., 2014).
BA capability is defined for the purpose of this paper as IT-enabled business capabilities (Pavlou \& El Sawy, 2010) which bring about competency in two areas - information management and analytic expertise (Kiron \& Shockley, 2011; Pavlou \& El Sawy, 2010). BA capability is thus a technologically enabled ability that can help process large volumes of high-velocity data, and several varieties of data insights (Fosso Wamba, Gunasekaran et al., 2017). BA use information technology (IT)-based tools, e.g., data warehouses, online analytical processing (OLAP), statistical and quantitative tools, visualisation tools and data mining tools (Gandomi \& Haider, 2015; Seddon et al., 2017). However, there is a consensus among academicians and practitioners that the main goal of BA is to prepare a suitable context in which firms can react properly to a changing environment (Kwon, Lee, \& Shin, 2014; Teo, Nishant, \& Koh, 2016). This has not only facilitated the way organisations manage their businesses (Bertsimas, Bradlow, Gans, \& Gupta, 2014) but also given them an opportunity to access timely and relevant data by integrating structured and unstructured information and aid decision-making (Cao, Duan, \& Cadden, 2019; Puklavec, Oliveira, \& Popovič, 2018; Rouhani, Ashrafi, Zare Ravasan, \& Afshari, 2016; Shollo \& Galliers, 2016; Teo et al., 2016).

It is crucial to investigate how and in which ways IT applications improve firm performance (Wade \& Hulland, 2004; Zhang \& Dhaliwal, 2009). To that end, Bharadwaj (2000) showed that IT capabilities are a key differentiator between higher- and lower-performing firms. Previous studies asserted that BA capabilities create possibilities for a rich analysis to help companies achieve a competitive advantage (Delen \& Demirkan, 2013; Larson \& Chang, 2016; Nam, Lee, \& Lee, 2018).

There is considerable evidence on the relationship between BA and both organisational (Germann, Lilien, \& Rangaswamy, 2013; Huang, Pan, \& Ouyang, 2014; Ramakrishnan et al., 2012; Viaene \& Van den Bunder, 2011) and operational performance (Chae, Yang, Olson, \& Sheu, 2014). For instance, Brynjolfsson, Hitt, and Kim, (2011) indicated that BA would provide a productive environment through data-driven decision-making in which firms can achieve higher performance. Similarly, Sangari and Razmi (2015) proposed a conceptual model to explore the potential role of BA in improving performance in the supply chain context.

An interesting question in this respect is how to measure analytical capabilities. A large number of emerging studies on the topic have used a multidimensional construct (e.g. (Akter et al., 2016; Fosso Wamba, Gunasekaran et al., 2017; Gupta \& George, 2016)) distinguishing between intermediate outcomes ('benefits' or 'functional performance') and impact on organisational performance ('business value' or 'firm performance') (Wang, Kung, Wang, \& Cegielski, 2018). However, we were most interested in analysing the general impact of BA on a conceptual level, which can manifest in many ways in different cases (Cimperman, Brenčič, \& Trkman, 2016). Since a large number of BA capability frameworks exist in both the academic and practitioner literature (Santiago Rivera \& Shanks, 2015) and definitions of BA vary (Cao, Duan, \& Li, 2015), the BA in our study were deliberately conceptualised as a single construct (as also suggested by LaValle, Hopkins, Lesser, Shockley, and Kruschwitz, (2010)). In such a way, we adopt a general core characterisation of BA as concerned with evidence-based recognition and problem-solving, which happen within the context of business situations using a single construct of BA's organisational benefits (Seddon et al., 2017). Such an approach was often used in similar studies, such as Vidgen, Shaw, and Grant, (2017), who measured BA simply by asking 'How often does your organisation use the following'? or Popovič et al. (2012), who investigated BA as a single construct including 'technology, data, process and organisation'.

In general, senior executives need analytics to extract information from existing data to help in decision-making and take action that would be almost impossible otherwise (LaValle et al., 2010). There is a 
consensus among academics and practitioners that BA provide higher performance through their inherent capabilities (Fosso Wamba, Gunasekaran et al., 2017; Peters, Wieder, Sutton, \& Wakefield, 2016; Shollo \& Galliers, 2016; Troilo, Bouchet, Urban, \& Sutton, 2016). Nevertheless, how BA influence performance remains unclear (Sharma et al., 2014). As the potential types of this impact are still not well understood, our paper intends to contribute to the literature by proposing a new way to understand how BA capability influences firm performance.

\subsection{Agility}

As also summarized by (Zhou, Mavondo, \& Saunders, 2018) the term agility has been used in numerous studies (Liu, Ke, Wei, \& Hua, 2013; Raschke, 2010; Sambamurthy, Bharadwaj, \& Grover, 2003; Son, Lee, Lee, \& Chang, 2014; Swafford, Ghosh, \& Murthy, 2008) from different business levels such as supply chain (Yusuf et al., 2014, Dubey, Gunasekaran, \& Childe, 2018), organization (Ghasemaghaei, Hassanein, \& Turel, 2017; Lu \& Ramamurthy, 2011), business process (Raschke, 2010), management (Winby \& Worley, 2014), among others. The common point in all the mentioned studies is this that enterprises need a special capability to face unforeseen changes in the marketplace. They must react swiftly to cope with rapid and unexpected changes-in a word, to be agile (Dove, 2001; Ganguly, Nilchiani, \& Farr, 2009; Tan, Tan, Wang, \& Sedera, 2017). Regarding supply chain context, agility is the ability of supply chain network to respond to the needs of the customers through high speed, high responsiveness and high flexibility to gain competitive edge over competitors in market (Dubey, Ali, Aital, \& Venkatesh, 2014). Scholars have defined supply chain agility as the ability of the firm to adjust tactics and operations within its supply chain to respond to environmental changes, opportunities, and threats (Dubey, Altay et al., 2018). From organization perspective, agility is the ability to sense opportunities for innovation and respond to those opportunities and to rapidly redesign processes to exploit marketplace conditions (Kitchens, Dobolyi, Li, \& Abbasi, 2018).

Seo and La Paz (2008) believe that agility includes different processes that provide an opportunity for a firm to sense environmental changes and respond to them in a timely and cost-effective manner. Teece, Peteraf, and Leih, (2016) defined agility as the "capacity of an organization to efficiently and effectively redeploy/redirect its resources to value creating and value protecting (and capturing) higheryield activities as internal and external circumstances warrant'.

Therefore, the ability to adapt to unforeseen changes in the global market is a fundamental element for surviving in such a turbulent environment (Ganguly et al., 2009). Three main practices, including analysing prior data, monitoring present activities and predicting the future, should be high priorities (Viaene \& Van den Bunder, 2011). On this basis, companies must maintain a process of preparing and adopting a supportive environment for appropriate decision-making (Delen \& Demirkan, 2013; Jaklič, Grublješič, \& Popovič, 2018; Rouhani, Ashrafi, Ravasan, \& Afshari, 2018; Stieglitz, Mirbabaie, Ross, \& Neuberger, 2018).

Despite the undeniable role of agility, a vast set of studies on ITrelated issues have overlooked agility as a potential outcome (Oh \& Pinsonneault, 2007) and only highlighted firm performance (e. g., Devaraj \& Kohli, 2003; Melville, Kraemer, \& Gurbaxani, 2004; Mithas, Ramasubbu, \& Sambamurthy, 2011; Rai, Patnayakuni, \& Seth, 2006; Stoel \& Muhanna, 2009). With some notable exceptions (Overby, Bharadwaj, \& Sambamurthy, 2006; Sambamurthy et al., 2003; Tallon \& Pinsonneault, 2011) previous research does not fully address the relationship between IT-related issues and firms' agility (Dutta, Lee, \& Yasai-Ardekani, 2014). More directly, the relationship between IT-enabled business capabilities and agility has been seen as a 'black box'
(Huang et al., 2014). To address this gap, there is a need to analyse how IT-enabled business capability in general and BA capability in particular can help the firm become more agile (Iș1k et al., 2013; Viaene \& Van den Bunder, 2011). Maintaining this ability is crucial because companies must be able to continually change their existing business model or add a new one in response to currently unknown changes (Trkman, Budler, Groznik, \& Wagner, 2015).

\subsection{Information quality}

Nowadays, the ability to take advantage of all available information is crucial (Olszak, 2016). Information quality is a central point that enables firms to improve their organisational performance (Chae et al., 2014; Petter, DeLone, \& McLean, 2008; Shen, Chang, Hsu, \& Chang, 2017). According to Shen et al. (2017), information quality indicates the quality of output from the information system in the form of reports or on-screen data. BA aims to improve the information used in the decision-making process (Fink, Yogev, \& Even, 2017; Kowalczyk \& Buxmann, 2015). Moreover, Popovič et al. (2012) showed that the quality of information therefrom depends on the level of BA maturity. Shen et al. (2017) declared that the quality of decisions is mainly structured based on BA's information quality; furthermore, Côrte-Real et al. (2017) believed that processing a large amount of information by applying BA is one possible way for firms to achieve agility.

\subsection{Innovation capability}

The term 'innovation' is the capacity of firms to find solutions to existing problems and respond to challenges in the market (Song, 2015). Previous research has widely discussed innovation as one of the significant strategic benefits obtained from using information systems (Wang, Kung, Wang et al., 2018). In line with Wang and Dass (2017), innovation capability is defined as 'a firm's ability to generate, accept, and implement new ideas, processes, products, or services'. IT capabilities focus on deploying IT-related resources within the organisation to improve firms' innovative capability (Wang et al., 2013). For instance, Zain, Rose, Abdullah, and Masrom, (2005) argued that use of IT capabilities increases the firms' performance through assisting in innovative activities.

\subsection{Environmental turbulence}

Generally speaking, 'turbulence' is the condition(s) of unpredictability in the environment and occurs because of rapid changes in customer needs, emerging technologies and competitive actions (Pavlou \& El Sawy, 2010). Environmental turbulence refers to 'the rate and instability of the environment, which is the result of changes in customer preference, development of new products, new technology, or the competition' (Stoel \& Muhanna, 2009). Based on previous research, we have decomposed this construct into technological turbulence and market turbulence (Jaworski \& Kohli, 1993). Technological turbulence implies 'the degree of unpredictable change in production or service technology' (Slater \& Narver, 1994). This definition clearly shows that a turbulent technological environment makes current technology obsolete and requires new ones to be developed (Hung \& Chou, 2013). Market turbulence means 'the rate of changes in the composition of customers and their preferences' (Slater \& Narver, 1994). Environmental turbulence was found to be an important moderator of the impact of several constructs on various aspects of performance (Kock \& Georg Gemünden, 2016), especially in decision-making (Chen, Neubaum, Reilly, \& Lynn, 2015). 


\section{Research model}

Based on the above arguments, we analyse the relationship between BA capabilities and firms' agility by considering information quality (DeGroote \& Marx, 2013; Gustavsson \& Jonsson, 2008) and innovation capability (Bayo-Moriones \& Lera-López, 2007; Rosenbusch, Brinckmann, \& Bausch, 2011) as the ways BA capability influences agility.

\subsection{Hypotheses development}

Enterprises attempt to capture the required information and analyse it in an accurate and timely fashion to prepare analytical insights for decision-makers (Sahay \& Ranjan, 2008; Trieu, 2017). IT in general and BA in particular prepare higher-quality information to make better decisions in a timely manner (DeGroote \& Marx, 2013; LaValle et al., 2010; Wade \& Hulland, 2004). Delen and Demirkan (2013) developed a taxonomy for BA capabilities and noted that BA is developed to offer comprehensive knowledge about the business to decision-makers and help them introduce more effective actions. Gustavsson and Jonsson (2008) explored the positive impact of IT usage within the organisation on information quality. The major mission of BA systems is to enable managers to make better decisions by preparing timely, relevant, and easy-to-use information (Elbashir, Collier, \& Davern, 2008; Lismont, Vanthienen, Baesens, \& Lemahieu, 2017; Rouhani et al., 2016), and Popovič, Hackney, Coelho, and Jaklič, (2014), who investigated the relationship between BI systems maturity and its impact on information quality, clearly showed that these systems enhance information quality. Therefore, we propose:

H1a. BA capabilities positively impact information quality.

Past studies showed that the importance of firms' capability to extract environmental information to reveal new business opportunities and evolve/innovate consistently (Bose, 2009; Chae, 2014; Wang \& Dass, 2017). The extracted data help managers find the most efficient way to uncover new business opportunities (Ashrafi \& Zare Ravasan, 2018; Howson, 2007; Sivarajah, Kamal, Irani, \& Weerakkody, 2017). Therefore, firms seek to develop innovative capability through various enterprise applications such as BA (March \& Hevner, 2007). Tamer Cavusgil, Calantone, and Zhao, (2003) ascertained that firms with higher innovation capability can achieve greater know-how in the market, making it problematic for other rivals to match or imitate them. The use of advanced BA tools allows firms to be more creative and test new ideas in a virtual environment before introducing them in reality (Rud, 2009). Bayo-Moriones and Lera-López (2007) found that most firms employ BA instruments to increase their innovative capability. Similarly, Işık et al. (2013) indicate that firms rely heavily on BA capabilities to make more entrepreneurial decisions through the discovery of new opportunities. Appropriate use of BA enables firms to generate new knowledge and insights for businesses (Sivarajah et al., 2017); thus, BA systems provide a holistic view for companies to make better sense of both their internal and external environments (Chung \& Tseng, 2012). Considering the above discussion, we posit the following hypothesis:

H1b. BA capabilities positively impact innovative capabilities.

Based on the definition of agility, firms should be able to detect and respond quickly to unexpected changes (Roberts \& Grover, 2012). However, despite the widely accepted importance of agility, there is limited research on this construct (Roberts \& Grover, 2012). Our understanding of how information quality transforms operations and generates improvements in organisational performance is also limited
(Popovic \& Habjan, 2012). We argue that the quality of information plays a fundamental role in sensing market changes and ensuring appropriate organisational decision-making throughout the firm. On the one hand, the quality of information shows the extent to which an organisation can accurately detect market and environmental changes and prepare an appropriate set of information for the decision-making process (2014, Popovič et al., 2012). Put simply, the quality of information is the basis for effective decision-making, which means an effective response to such changes (Li \& Lin, 2006; Shen et al., 2017; Swafford et al., 2008). Companies should leverage information as a fundamental asset to cope with these situations successfully (Newman \& Logan, 2006). In other words, firms' responses to change is differentiated by their information quality. As argued by Zain et al. (2005), there is a positive relationship between the information quality and agility in the firm. Thus, we propose:

H2. Information quality positively impacts the firm's agility.

As Rud (2009) notes, innovation is the crucial factor in adaptability to environmental pressure. Innovation capability arises as a key differentiator for gaining and sustaining competitiveness (Rud, 2009). This internal capability prepares a context in which firms will be able to swiftly carry out innovation (Yu, Dong, Shen, Khalifa, \& Hao, 2013). The outcome of Rosenbusch et al. (2011) shows that putting innovative ideas into practice is the only way to achieve the required adaptability. As van Oosterhout, Waarts, and van Hillegersberg, (2006) note, to gain agility, companies should be capable of responding to changes in a timely and innovative manner. Therefore, it is apparent that innovative capability can be seen as a prerequisite for achieving agility (Esterhuizen, Schutte, \& Du Toit, 2012). Laursen and Thorlund (2010) believed that using BA in firms' processes provides leading information for organisations and allows them to be more innovative than their major competitors. Furthermore, Tan et al. (2017) indicated that using IT systems not only increases the potential to continuously innovate but also prepare a supportive environment to achieve agility within the organisation. We therefore posit:

H3. Innovative capability positively impacts the firm's agility.

If an organisation is proficient at changing, it will have a greater chance of adapting to unpredictable changes in an efficient and timely manner (Ganguly et al., 2009). Agility has thus been considered to have a major impact on a firm's success (Dove, 2001; Overby et al., 2006) and sometimes even as a performance outcome, rather than a structural or operational characteristic (Yauch, 2011). Several studies have proven the impact of agility and related attributes on business performance (Chakravarty, Grewal, \& Sambamurthy, 2013; Côrte-Real et al., 2017; Wagner, Beimborn, \& Weitzel, 2014; Yusuf et al., 2014). Further, a recent study showed that agility impacts performance in various industries and environments (Gligor, Esmark, \& Holcomb, 2015). Teece, Pisano, and Shuen, (1997) argued that there is a positive relationship between an organisation's dynamic capabilities and its competitive performance; in line with Sherehiy et al. (2007), we believe that firm agility is not a goal in itself but a way for improving performance. Therefore, we propose:

\section{H4. Firm agility positively impacts firm performance.}

To deal with turbulence and uncertainty, organizations require agility in their supply chains to provide superior value and to ensure uninterrupted service to customers (Chen, 2018). The issue of environmental turbulence has been divided into two main categories: technological turbulence and market turbulence (Slater \& Narver, 1994). Trkman and McCormack (2009) claimed that firms within a stable market might achieve an average performance with a flawed 


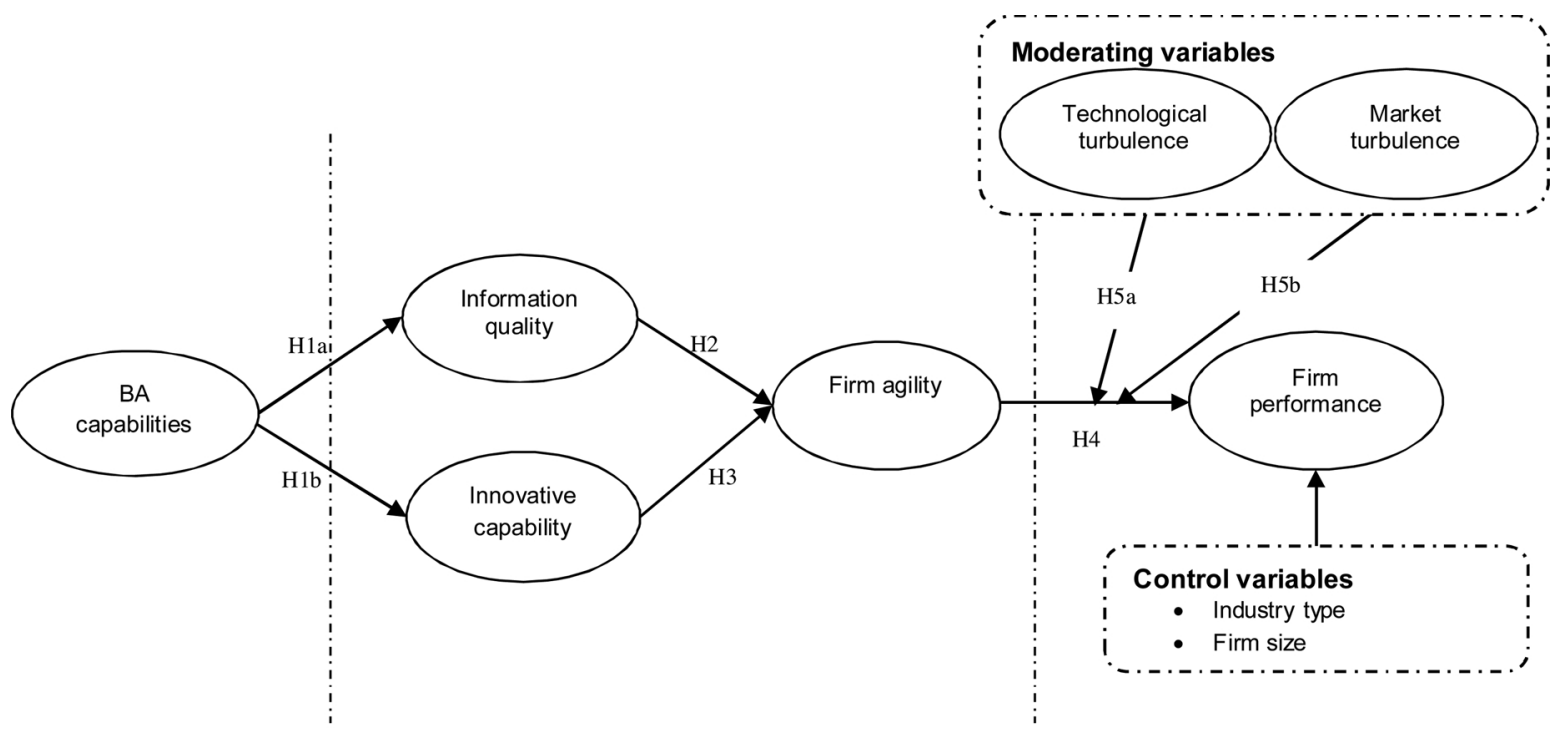

Analytics level

$\underline{\text { Capability }}$

Competitive advantage

Fig. 1. Conceptual model.

strategy or structure, while the same firms in a turbulent environment will encounter significant difficulties. In many cases, it is impossible to remove all sources of uncertainty within a specific market; for this reason, firms seek a new way to cope with it effectively. Hitt, Keats, and DeMarie, (1998) noted that to operate in turbulent environments, firms must prepare and develop a special set of capabilities. Moreover, they believed that although these competencies enable firms to meet their strategic goals, they should be continually developing. In other words, in a turbulent environment, the need to sense and respond to environmental changes is crucial. Jaworski and Kohli (1993) believed that a high level of variation in customer preferences would hasten the obsolescence of past market knowledge. Thus, firms in such turbulent markets must quickly respond to latent customer needs (Hung \& Chou, 2013; Lee, Sambamurthy, Lim, \& Wei, 2015; Trinh-Phuong, Molla, \& Peszynski, 2012). As Bhatt, Emdad, Roberts, and Grover, (2010) argued, firms that respond slowly to changes in the market may lose opportunities or even lag behind competitors. Similarly, Trinh-Phuong et al. (2012) stated that organisations operating in turbulent environments face higher uncertainty and thus need to process information more rapidly than organisations that operate in more stable business surroundings. Hence, agility could be a suitable trait to act as a special capability in achieving competitive advantage in a turbulent environment. In this regard, the outcome of Tallon and Pinsonneault (2011) showed that agility has a greater impact on firm performance in a volatile environment than in a stable one. Therefore, we propose:

H5a. Technological turbulence positively moderates the relationship between agility and the firm's performance.

H5b. Market turbulence positively moderates the relationship between agility and the firm's performance.

Fig. 1 shows the research model.

\section{Research method}

\subsection{Instrument development}

Our questionnaire used scales to measure the various factors of the research model. With an acceptable level of error of $10 \%$, we used a five-point Likert scale to measure the constructs for all survey items (except for control variables). To assess content validity, seven CIOs and five CEOs with at an academic degree and more than eight years of working experience reviewed the questionnaire items and structure. Their comments on the clarity and length of some items were applied in the revised version of the questionnaire. Furthermore, the test-retest reliability method was conducted in a 14-day interval using 15 experts' responses, which yielded Cronbach's alpha equal to 0.84 (above the threshold level of 0.70 ).

\subsection{Data sample}

A 'survey' is a research strategy in which experts on a particular subject are asked about their perception of relevant organisational aspects (Rungtusanatham, Choi, Hollingworth, Wu, \& Forza, 2003). A survey allows for a closer relationship between academia and the real world because it facilitates the testing of conceptual models based on real-world data (Flynn, Sakakibara, Schroeder, Bates, \& Flynn, 1990), which makes this approach appropriate for the current research.

The research objects in this study were companies from a wide range of industries in Iran, identified in a database of the 500 Iranian companies with the largest revenue (Donya-e-Eghtesad, 2016). The motivation for conducting this study in the Iranian context derives from prior evidence suggesting that successful transitions in the context of economic and political upheavals are often associated with relatively advanced business practices (Cadez \& Guilding, 2008). Several previous studies have successfully used Iranian data for general findings. Keramati, Mehrabi, and Mojir, (2010) showed a high validity and reliability of data collected by investigating the influence of customer relationship process and capabilities on firms' performance; a similar study analysed the benefits derived from BA in the supply chain context of Iranian automotive manufacturers (Sangari \& Razmi, 2015). As argued by Albadvi, Keramati, and Razmi, (2007), creativity and innovation are flourishing as Iranian industry enters the international competitive arena. Another study in an Iranian setting investigated how IT can help companies that are inflexible and lack business agility to improve performance (Alaeddini \& Salekfard, 2013). Recently, Abdolvand 
Table 1

Demographics of the firms (number of organizations $=154$ ).

\begin{tabular}{ll}
\hline Category & Percentage of respondents \\
\hline Industry type & \\
Information Technology (IT) & $16.2 \%$ \\
Manufacturing & $13.6 \%$ \\
Electrical \& Electronics & $13.0 \%$ \\
Bank, Insurance, Investment & $11.7 \%$ \\
Dairy, Food \& Meat Products & $8.4 \%$ \\
Retail/Wholesale/Distribution & $7.8 \%$ \\
Automobile Dealership & $5.8 \%$ \\
Chemical \& Pharmaceuticals & $5.2 \%$ \\
Medical \& Healthcare & $4.5 \%$ \\
Transportation, Logistics \& Courier & $3.9 \%$ \\
Telecommunications & $3.2 \%$ \\
Other & $6.5 \%$ \\
Revenue (US\$ million) & \\
Over 100 & $21.4 \%$ \\
$51-100$ & $30.5 \%$ \\
11-50 & $29.2 \%$ \\
Less than 10 & $11.7 \%$ \\
Missing data & $7.1 \%$ \\
Number of company employees & \\
Fewer than 50 employees & $21.4 \%$ \\
$51-100$ employees & $16.2 \%$ \\
101-500 employees & $20.8 \%$ \\
501-1,000 employees & $17.5 \%$ \\
1,001-10,000 employees & $27.3 \%$ \\
\hline
\end{tabular}

and Sepehri (2016) found the Iranian setting to be proper for investigating the strategic alignment's antecedents in theory generalizability.

\subsection{Data collection}

In reaching out to the target sample, four steps were followed. As suggested by Chen, Lin, and Chang, (2009), each company was first contacted by phone. This pre-notice discovered or confirmed the names and job titles of the respondents and briefly explained the major aims of the research and the questionnaire contents. They were also notified that they would be requested within a few days to complete the survey questionnaire. The survey's direct link and main request cover letter were sent out within a day after the pre-notice asking them to complete the questionnaire within two weeks. The cover letter explained the purpose of the research and assured respondents that answers would remain confidential. We also indicated in the cover letter that we would provide a summary of the survey results in exchange for participation. The third contact (first reminder) was conducted through follow-up telephone calls, and emails sent one week later to those who did not respond to the initial request. One week after the first reminder, the second reminder was sent out to non-respondents.

Previous research has typically used only one respondent per organization. However, BA is a complex phenomenon influencing both IT and the company in general, and thus one person cannot provide comprehensive answers to all questions. In our case, the respondents for 'BA capabilities' and 'information quality' were CIOs, while those for 'innovative capability', 'firm agility', 'technological turbulence', 'market turbulence', and 'firm performance' were CEOs. By using two informants in each company, differing perspectives were obtained within the hierarchy of the firm on its practices, competencies and consequences, as suggested by Kock \& Georg Gemünden (2016). We sent
493 questionnaires to sample companies from June to August 2015; 154 valid and 24 invalid questionnaires were returned, entailing an effective response rate of $31.23 \%$. The profile of the responding firms is shown in Table 1.

\subsection{Measurement items}

We measured BA capabilities on a five-item scale adapted from LaValle et al. (2010). These measures asked each respondent to determine the level of their firms' analytics capabilities in order to evaluate the extent of their use throughout the company (Davenport \& Harris, 2007; Someh \& Shanks, 2015).

Different measurements were used in previous studies to assess information quality (Popovič et al., 2012) and innovative capability (Yu et al., 2013); we adapted a five-item scale on the former from (Delone \& McLean, 2003; Li \& Lin, 2006). and a four-item scale measurement based on Wang et al. (2015) for the latter. The items represent how well the organisation is capable of creating new ideas and introducing new ways to market a product/service.

The term 'agility' is defined from various perspectives, and different measures were used in previous studies (Sherehiy et al., 2007; Zain et al., 2005). Here, we assess firm agility based on an eight-item scale developed by Tallon and Pinsonneault (2011). The construct measures agility in three areas - customer responsiveness, business partnership and business operations - as originally developed by Sambamurthy et al. (2003). We measured technological turbulence with a two-item scale adapted from Pavlou and El Sawy (2010); to assess market turbulence, we employed a three-item scale adapted from the same study.

In the past, diverse measurements were adopted to evaluate firms' performance (Liu et al., 2013). In line with Venkatraman and Ramanujam (1986), we used self-reported evaluation of financial performance because innovative managerial efforts cannot be measured with solely financial performance indicators. In line, the respondents are requested to state their firm's perceived performance (Gunday, Ulusoy, Kilic, \& Alpkan, 2011). We used a four-item scale based on Chen et al. (2014). The items assess how well an organisation performs in comparison with its competitors and include return on investment, market share, sales growth and overall profitability. The whole questionnaire is included in Appendix A.

\subsubsection{Control variables}

Past studies (e.g., Seddon et al., 2017; Yeoh \& Popovič, 2016) have recommended considering firm size and industry sector as control variables in the context of BA. We included firm size, as larger firms may have more resources than smaller firms, which may affect the relationship between agility and a firm's performance (Tippins \& Sohi, 2003). In other words, large firms can invest in different activities that support IT, such as employee training (Subramani, 2004). We utilised a categorical description of the firm's size following Judge and Elenkov (2005)—specifically, we classified firms with fewer than 100 employees as 'small', firms with more than 100 employees but fewer than 1000 employees as 'medium', and firms with more than 1000 employees as 'large'. We also controlled for industry sub-types because they can capture different environmental dimensions, which may impact constructs and relationships in the model.

\section{Data analysis}

This study employed PLS technique and SmartPLS (v. 3.2.7) 
Table 2

Discriminant validity of the constructs (heterotrait-monotrait ratio (HTMT) test).

\begin{tabular}{llllllllll}
\hline Constructs & 1 & 2 & 3 & 4 & 5 & 6 & 7 & 8 & 9 \\
\hline 1 BA capabilities & & & & & & & & \\
2 Information quality & 0.61 & & & & & & & \\
3 Innovative & 0.47 & 0.36 & & & & & & \\
$\quad$ capability & & & & & & & & \\
4 Firm agility & 0.40 & 0.47 & 0.37 & & & & & & \\
T Technological & 0.36 & 0.44 & 0.36 & 0.27 & & & & \\
$\quad$ turbulence & & & & & & & & \\
6 Market turbulence & 0.28 & 0.39 & 0.29 & 0.25 & 0.47 & & & \\
7 Firm performance & 0.48 & 0.29 & 0.22 & 0.31 & 0.18 & 0.19 & & \\
$\quad$ 8 Industry type & 0.06 & 0.03 & 0.09 & 0.10 & 0.02 & 0.04 & 0.09 & \\
9 Firm size & 0.04 & 0.05 & 0.05 & 0.04 & 0.06 & 0.05 & 0.08 & 0.04 \\
\hline
\end{tabular}

software for data analysis Ringle Wende and Becker, 2015. PLS was chosen for four reasons. First, the PLS-SEM approach has a broad scope and is flexible with regard to theory and practice (Richter, Cepeda, Roldán, \& Ringle, 2016). Second, it can be used to address small sample sizes (Hair, Hult, Ringle, \& Sarstedt, 2017), which we have. Third, our data contains a categorical dataset with an unknown non-normal frequency distribution, which also favours the use of PLS. Fourth, in complex models, PLS-SEM is 'virtually without competition' (Richter et al., 2016). SmartPLS supports two levels of assessments: (a) the measurement model (e.g., item reliability, convergent and discriminant validities) and (b) the structural model assessment (e.g., path coefficients and $\mathrm{R}^{2}$ values in the model), which are presented in the following sections.

\subsection{Assessment of the measurement model}

To assure constructs' internal consistency, Cronbach's alpha and composite reliability indicators should be between 0.7 and 0.9 (Hair et al., 2017); for convergent validity, average variance extracted (AVE) values should be at least 0.50 , which means that each construct explains more than $50 \%$ of the variance of its indicators. The factor loadings of all measurement items should also be above 0.70 (Hair et al., 2017). The resulting Cronbach's alpha, composite reliability, factor loading and AVE values (see Appendix B) are all above the threshold values.

Discriminant validity indicates the extent to which measures of different constructs are distinct from each other. In order to test discriminant validity, the Heterotrait-Monotrait (HTMT) ratio of correlations has been applied here. HTMT is the average of the Heterotrait-Heteromethod correlations (i.e., the correlations of indicators across constructs measuring different phenomena) relative to the average of the Monotrait-Heteromethod correlations (i.e., the correlations of indicators within the same construct). The HTMT should be significantly smaller than one (ideally $<0.85$ ) in order to evidently distinguish between two factors (Henseler, Ringle, \& Sarstedt, 2015; Henseler, Hubona, \& Ray, 2016). In our case, HTMT ratios for each pair are $<0.85$ (see Table 2), hence indicating all constructs are explicitly independent of each other and that the criterion for discriminant validity has been met.

\subsection{Assessment of the structural model}

Given an adequate measurement model, our hypotheses can be tested by examining the structural model. We applied the SEM procedure based on SmartPLS (v. 3.2.7) to analyse Stone-Geisser's $Q^{2}$, standardised root mean square residual (SRMR), RMS_theta, goodnessof-fit, coefficient of determination $\left(\mathrm{R}^{2}\right)$ and path coefficients. Path coefficients, $t$-values and $p$-values for control variables as suggested by Becker et al. (2016) and Bernerth and Aguinis (2016) are also depicted in Table 3. To gauge the statistical significance of the path coefficients, following Streukens and Leroi-Werelds (2016) for the PLS-SEM context, the bootstrapping process was conducted using 10,000 randomly generated sub-samples to boost the level of accuracy. Predictive relevance $\left(\mathrm{Q}^{2}\right)$ was measured using the blindfolding procedure (the cross-validated redundancy approach), which represents a measure of how well the path model can predict the originally observed values (Hair et al., 2017). All $Q^{2}$ values were substantially above zero, providing strong support for the high predictive relevance of the model (see Table 3).

In the SRMR, the model has a good fit, with a value of 0.06 , is well below the threshold level of 0.08 (Henseler et al., 2014). RMS_theta is also equal to 0.12 , which is the root squared residual covariance matrix of the outer model residuals (Lohmöller, 1989). RMS_theta value below 0.12 indicates a well-fitting model, whereas higher values indicate a lack of fit (Henseler et al., 2014). Moreover, the model's overall Goodness-of-Fit (GoF) is equal to 0.53 obtained using the equation: $\mathrm{GoF}=\sqrt{A \bar{V} E \times \bar{R}^{2}}$ (Alolah, Stewart, Panuwatwanich, \& Mohamed, 2014). This equation considers the average AVE of the model's seven latent variables and average $\mathrm{R}^{2}$ of the four endogenous latent variables. Moreover, the GoF index has been computed for each dependent variable using the respective AVE and $\mathrm{R}^{2}$. Considering the GoF criteria of small: 0.1 , medium: 0.25 , and large: 0.36 and the GoF values reported in Table 3 , it can be argued that the proposed model has a suitable

Table 3

Summary of the PLS results.

\begin{tabular}{|c|c|c|c|c|c|c|c|c|c|}
\hline Dependent variable & Independent/control variable & Hypothesis & Path coefficient & t-value & $\mathrm{p}$-value & Result & $\mathrm{R}^{2}$ & $\mathrm{Q}^{2}$ & GoF \\
\hline \multirow[t]{2}{*}{ Information quality } & BA capabilities & H1a & $0.35^{* * *}$ & 8.31 & 0.000 & Supported & 0.29 & 0.27 & 0.44 \\
\hline & BA capabilities & H1b & $0.47 * * *$ & 9.14 & 0.000 & Supported & 0.36 & 0.34 & 0.48 \\
\hline \multicolumn{10}{|c|}{ Innovative capability } \\
\hline & Information quality & $\mathrm{H} 2$ & $0.17 * * *$ & 4.78 & 0.000 & Supported & 0.44 & 0.41 & 0.54 \\
\hline \multicolumn{10}{|l|}{ Firm agility } \\
\hline & Innovative capability & H3 & $0.22 * * *$ & 5.41 & 0.000 & Supported & & & \\
\hline & Firm agility & $\mathrm{H} 4$ & $0.45^{* * *}$ & 9.72 & 0.000 & Supported & 0.54 & 0.47 & 0.57 \\
\hline \multicolumn{10}{|l|}{ Firm performance } \\
\hline & Technological turbulence $\times$ Firm agility & H5a & $0.23^{* *}$ & 3.15 & 0.002 & Supported & & & \\
\hline & Market turbulence $\times$ Firm agility & H5b & $0.16^{*}$ & 2.56 & 0.011 & Supported & & & \\
\hline & Industry type & Control variable 1 & 0.02 & 0.45 & 0.653 & Not supported & & & \\
\hline & Firm size & Control variable 2 & 0.04 & 0.56 & 0.576 & Not supported & & & \\
\hline
\end{tabular}




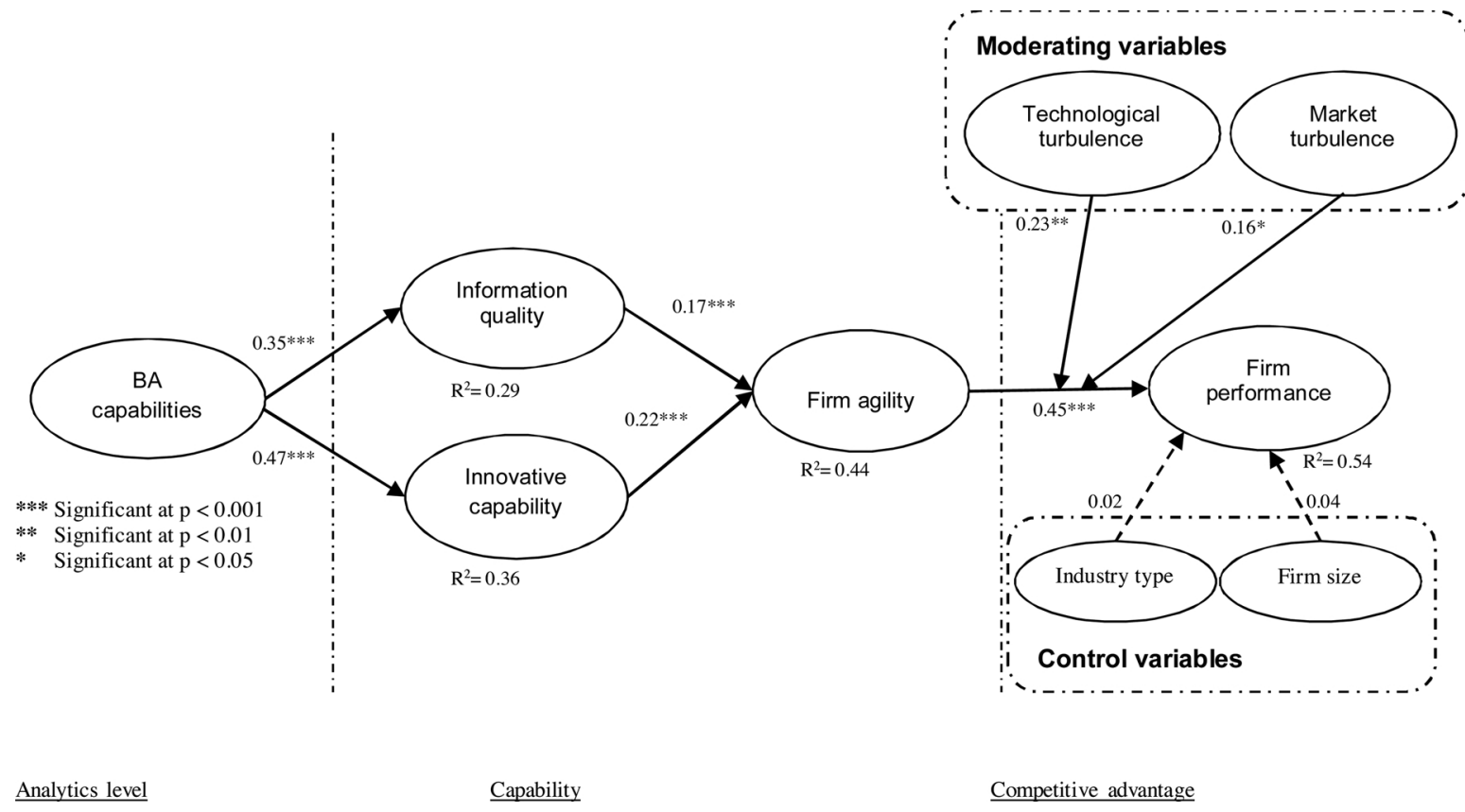

Fig. 2. The PLS analysis results for the research model.

overall fit. Finally, according to the $\mathrm{R}^{2}$ coefficients, the modelled constructs explain a moderate amount of $54 \%$ variance of firm performance, followed by firm agility (44\%), innovation capability (36\%) and information quality (29\%). They all lie at satisfactory levels above 0.26 $\left(\mathrm{R}^{2}\right.$ small $=0.02 ; \mathrm{R}^{2}$ medium $=0.13 ; \mathrm{R}^{2}$ large $\left.=0.26\right)($ Cohen, 1992). On the other hand, a considerable portion of the unexplained variances indicate that other factors beyond the scope of the proposed conceptual model could improve explanations of dependent variables.

\subsection{Common method variance}

Common method variance (CMV) in self-report surveys is one of the methodological sources of measurement error with a potential to lessen the reliability and validity of underlying constructs and postulated relations in a model (Malhotra, Schaller, \& Patil, 2017). In the current study, several techniques were used to assess CMV and minimize its potential effects. At First, based on Podsakoff, MacKenzie, and

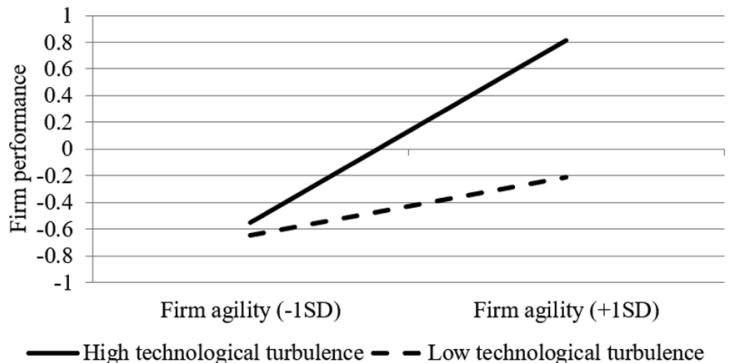

a) technological turbulence $\times$ firm agility $\rightarrow$ firm performance
Podsakoff, (2012) procedural remedies, we tried to increase the questionnaire readability by using clear and concise language, avoiding complicated and double-barrelled questions, defining ambiguous or unfamiliar terms and labelling all scale points, not just the ends. Participants were assured that their identities and responses would remain entirely anonymous, which could cause them to be less likely to edit their responses and have less evaluation apprehension. The emphasis was also placed on honest answers. Second, several crosschecks were performed to increase the reliability of the questionnaire. And finally, the results of the structural model demonstrated different levels of significance for the path coefficients. In sum, the arguments above support to the conclusion that CMV is not strong enough to bias this study.

\subsection{Interpretation of results}

Based on the results (see Table 3 and Fig. 2), hypothesised path H1a

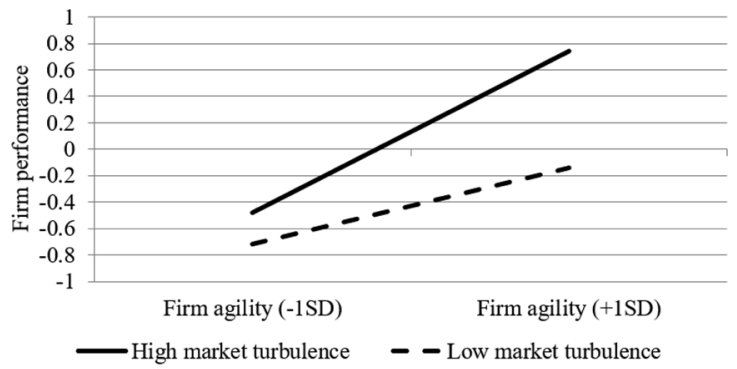

b) market turbulence $\times$ firm agility $\rightarrow$ firm performance

Fig. 3. Plots of simple slopes to account for the interaction eff ;ects. 
between BA capabilities and information quality $(\beta=0.35, \mathrm{t}=8.31)$ was supported. The data confirmed hypothesis $H 1 b$, which suggested a significant, positive relationship between BA capabilities and innovative capability $(\beta=0.47, t=9.14)$. Likewise, the data confirmed hypothesis $\mathrm{H} 2$, in which information quality was found to have a significant positive relationship with firm agility $(\beta==0.17, t=4.78)$. The analysis results supported hypothesis $\mathrm{H} 3$ indicating that innovative capability and firm agility are positively related $(\beta=0.22, t=5.41)$. Hypothesis $\mathrm{H} 4$ was also supported, suggesting that firm agility and firm performance are positively related $(\beta=0.45, t=9.72)$. The preceding constructs altogether explained a total of $54 \%$ of the variance in the firm performance as the model's dependent construct.

Furthermore, to address the moderation effects (H5a and H5b) of technological turbulence and market turbulence between firm agility and firm performance, the two-stage approach using an interaction term of a) technological turbulence $\times$ firm agility and b) market turbulence $\times$ firm agility with standardized indicators were applied (Fassott, Henseler, \& Coelho, 2016; Hair et al., 2017). The model obtained an explanatory power of $54 \%$ with the significant path coefficient of $0.23(t=3.15)$ for technological turbulence $\times$ firm agility $\rightarrow$ firm performance and $0.16(t=2.56)$ for market turbulence $\times$ firm agility $\rightarrow$ firm performance.

Finally, it is also important to consider the standard criteria for structural model assessment. In the context of moderation, $\mathrm{f}^{2}$ effect size of the interaction effect should be assessed which enables an assessment of the change in the $\mathrm{R}^{2}$ value when an exogenous construct is omitted from the model. In case of the interaction effect, the $\mathrm{f}^{2}$ effect size indeed indicates how much the moderation contributes to the explanation of the endogenous latent variable and is calculated employing the following equation (Fassott et al., 2016):

$\mathrm{f}^{2}=\frac{\mathrm{R}_{\text {Moderator included }}^{2}-\mathrm{R}_{\text {Moderator excluded }}^{2}}{1-\mathrm{R}_{\text {Moderator included }}^{2}}$

Taking into account the conventional criteria for assessing the eff ;ect size of moderation ( 0.02 for small, 0.15 for medium, and 0.35 for large effects (Cohen, 1988)), the achieved effect size of 0.085 and 0.062 (for technological turbulence and market turbulence moderating effects, respectively) represent small to medium effect sizes. Then, the results show that technological turbulence (H5a) and market turbulence (H5b) positively moderates the effects of firm agility on firm performance. To aid interpretation, we plot the test results in Fig. 3, using -1 and +1 Standard Deviation (SD) as the low and high values of the variables. In the interaction effects plots, the slope (rather than absolute values) of the relationship between the predictor and the dependent variable for varying levels of the moderator should be interpreted (Hair et al., 2017). Taking into account the positive moderating effects, the steeper slope of the solid line compared to the dotted line illustrates that an increase in firm agility is associated with a larger (smaller) increase in firm performance when technological turbulence / market turbulence is high (low).

Finally, turning to research control variables, it should be noted that the proposed control variables (industry type, firm size) do not depict a significant influence. In other words, firms of a different industry type or size do not significantly differ regarding the relationship between firm agility and firm performance. Thus, we can stipulate that the development of BA capabilities can be similarly beneficial for various industries and firm sizes.

\section{Discussion, implications and future research}

The purpose of this study is to investigate the influence of BA capabilities on firm agility and performance. The empirical results demonstrate that BA capabilities increase firms' agility to sense market changes by improving information quality, and enable firms to respond to market changes by developing innovative capability. The results also indicate that the relationship between agility and performance can vary by considering the moderating effect of environmental turbulence. Our findings on the effects of BA capabilities, information quality, innovative capability and firms' agility are not only consistent with prior studies, but offer new insights into the association between all of these in improving firm performance.

\subsection{Implications for research}

This study has several theoretical implications for BA research. First, although several studies have explored the impact of BA on firm performance, the present research is among the first studies to consider firm agility as a way to reach this goal. We highlight the significant importance of sensing and responding to the market environment in BA environment, and used survey data from 154 firms to provide empirical support for the relationship between BA capabilities, firm agility and firm performance in uncertain environments. In addition, while both information quality and innovative capability were widely discussed in prior research, to the best of our knowledge, the current research is the first study that theoretically argues that these items are a leveraging point in a BA context to increase firm agility. Actually, this study contributed to the answer about how BA contribute to firms' agility and then performance. Our findings reveal that both information quality and innovation capability not only influenced by BA capabilities but also clearly inform the literature on how influence firms' agility. Furthermore, the outcome of this study adds further theoretical knowledge by analysing and measuring the moderating effect of environmental turbulence on the relationship between firm agility and performance. Based on our analysis, the positive effect of firm agility on performance are evident only in highly turbulent environments. It shows itself when firms face several difficulties in either market or technological aspects and need a very fast response. Our results show that firms with higher capability in responding to environmental changes have higher performance than others. Thus, it would make a distinguishing point between firms in high environmental turbulence.

\subsection{Implications for practice}

Although BA capabilities play an important role in advancing firm performance (Germann et al., 2013), the empirical evidence for illuminating how and in which way it happens is incomplete. Our study contributes to the understanding of how the presence of superior BA capabilities within a firm can improve firms' agility by increasing information quality and innovative capability. Our results show strong links between BA and information quality (H1a) and between information quality and firm agility (H2). This finding shows that only relevant and high-quality information helps firms to adapt to market environments (Chen et al., 2014; Rouhani et al., 2016). Sambamurthy et al. (2003) discussed how IT supports agility and information quality through digital options (IT-enabled capabilities). Previous research obviously mentioned that firms rely on their information systems to provide high-quality information (Chen et al., 2012; Popovič, Hackney, 
Tassabehji, \& Castelli, 2018). In a similar vein, Xu, Frankwick, and Ramirez, (2016) also argued that BA not only provide high-quality information but also prepare an opportunity for firms to tailor their responses based on changing environments. Thus, it is obvious that highquality information derived from BA equips managers to understand the current state of the business and, more importantly, recognise business threats and opportunities. These findings are valuable in helping managers understand the paramount role of BA capabilities in achieving quality information and agility; in other words, BA-enabled information has higher quality and could help managers more directly in making decisions.

Similarly, the outcome of our research has revealed that BA capabilities improve innovative capability, which is positively related to firms' agility. In this regard, Howson (2007) declared that data accessibility is less important than the way in which companies consume it. According to Calantone, Cavusgil, and Zhao, (2002) and LealRodríguez, Roldán, Ariza-Montes, and Leal-Millán, (2014), innovation capability enables firms to respond faster to the changing environment. IT seems to be a driving force in pursuing fast and innovative measures in the volatile marketplace (Chen et al., 2014; Lu \& Ramamurthy, 2011; Popovič et al., 2018). BA assimilate new knowledge across business departments and equip managers with new knowledge in order to respond to market changes. Considering this finding, managers should take the significant role of appropriate data processing/analysis into account to discover new knowledge and promptly respond to opportunities/challenges (Sivarajah et al., 2017). Thus, firms with higher potential to innovate have more chances to continuously develop their products/services and respond to changes in customers' preferences.

Moreover, this research finds that the impact of BA capabilities on innovation capability is relatively stronger than that on information quality. This may be due to the intrinsic nature of BA. Nowadays, firms with capable IT systems and software aiding their business processes can achieve sufficient information quality. However, they need to rely on the special capability of BA to provide an appropriate answer to 'What is happening'? or 'What will/should happen'? to innovate their product or business model.

Our analysis also proves the moderating effect of both technological and market turbulence on the link between agility and performance. This enterprise agility is less needed in relatively stable environments (see also Overby et al. (2006); Nevo and Wade (2010). The positive effect of agility on performance is stronger in a highly turbulent context where firms encounter several difficulties in forecasting rapid changes in technological and market demands and must respond to these changes. While a firm's low level of agility may be permissible in a nonturbulent environment, this may not be the case in the presence of technological changes (Overby et al., 2006). This issue clearly highlights how firm agility would be competitive leverage in an uncertain environment.

\subsection{Limitations and avenues for future research}

The study has several limitations. First, there may be other capabilities and ways that can lead to higher firm performance. Second, because of the cross-sectional nature of this study (the required data for the hypotheses were verified through completing a questionnaire at one specific point in time), we are unable to fully understand the dynamics among BA capabilities, agility and performance over time. Third, we conducted the study only within one developing country (Iran). Because the majority of studies about IT and agility were performed in developed countries (i.e., DeGroote \& Marx, 2013; Sambamurthy et al., 2003; Tallon \& Pinsonneault, 2011), our findings in developing countries should be generalized with caution. Yayla and Hu (2012) and Zare Ravasan and Mansouri (2016) asserted that several issues, such as cultural and structural differences between developed and developing countries, may cause variations in research outcomes; sanctions-related issues in the specific context of Iran should also be considered. US and UN sanctions against Iran in the last decades banned international IT application and service providers to participate in Iranian market; thus, Iranian firms have to rely on local service providers to fulfill their IT needs (Hanafizadeh \& Zare Ravasan, 2018). However, for our constructs (as also discussed in Section 4.2. Data sample), we believe that none of the concerns mentioned above has a significant impact on the generalizability of the research outcomes, even more so since Iran's management system seems to be a hybrid of Western, ancient and Islamic styles (Abdolvand \& Sepehri, 2016). Fourth, BA is a relatively new term, and there does not seem to be an established academic definition (Bichler, Heinzl, \& van der Aalst, 2017). Reviewing the literature shows that BA includes several functions and tools to support the strategic decision-making process by preparing an appropriate decision-support environment; the present paper only mentioned BA on a conceptual level and did not delve into the functional details. Thus, the paper could be criticised in terms of its discriminatory power for different types of BA capabilities within a firm.

This research provides several topics for future studies. First, subsequent studies could replicate our methods in other contexts (e.g., developed countries) and compare the results with this study or use a longitudinal study to address the limitations of the cross-sectional nature of this study. In-depth case studies would also be beneficial to provide more complete understanding. In addition, further research could examine other possible ways in which BA capabilities increase firms' performance. In all these efforts, it is important to clearly define the BA construct in such a way to avoid tautological findings. For example, if BA are defined as a tool that brings better decision making or 'delivering the right decision support to the right people at the right time' (Laursen \& Thorlund, 2010), then any impact of BA on information quality is tautological. Further research should acknowledge the specifics of contemporary BA applications (i.e. descriptive, predictive, prescriptive applications) and separately analyse the impact of specific analytics methods, techniques and models, such as data cleansing and data mining methods, on various facets of performance. Such research would provide more specific guidelines on what kind of BA a company in a particular situation should focus to be more likely to improve its performance.

\section{Acknowledgments}

The authors would like to thank the editor-in-chief Yogesh Dwivedi, the associate editor Rameshwar Dubey, and two anonymous reviewers for their extremely constructive and useful comments which helped to considerably improve the paper throughout the revision process.

Peter Trkman acknowledges the financial support of the Slovenian Research Agency (grant no. J5-9329). 


\section{Appendix A}

Table A1.

Table A1

Questionnaire used in the survey.

\begin{tabular}{|c|c|}
\hline Constructs & Source \\
\hline BA capabilities & adapted from (LaValle et al., 2010) \\
\hline \multicolumn{2}{|c|}{ To what extent do you agree with the following items in your organization: } \\
\hline \multicolumn{2}{|c|}{$\begin{array}{l}\text { 1) The organization predicts and prepares for the future by proactively evaluating scenarios or potential trade- } \\
\text { offs }\end{array}$} \\
\hline \multicolumn{2}{|c|}{ 1) Decision making is based on rigorous analytic approaches (e.g., quantitative modelling, simulation) } \\
\hline \multicolumn{2}{|c|}{$\begin{array}{l}\text { 1) The organization manages data to enable the ability to share and aggregate data across departments or } \\
\text { business units }\end{array}$} \\
\hline \multicolumn{2}{|c|}{ 1) Business information and analytics differentiate us within the industry } \\
\hline \multicolumn{2}{|c|}{ 1) Improving our information and analytics capability is a top priority } \\
\hline \multicolumn{2}{|c|}{ 1: Strongly disagree 5 _. Strongly agree } \\
\hline Information quality & $\begin{array}{l}\text { Developed based on (Delone \& McLean, 2003) and (Li \& Lin, } \\
\text { 2006) }\end{array}$ \\
\hline \multicolumn{2}{|c|}{ To what extent do you agree with the following items in your organization: } \\
\hline \multicolumn{2}{|c|}{ 1) The output information is timely. } \\
\hline \multicolumn{2}{|c|}{ 1) The output information is accurate. } \\
\hline \multicolumn{2}{|c|}{ 1) The output information is complete. } \\
\hline \multicolumn{2}{|l|}{ 1) The output information is adequate. } \\
\hline \multicolumn{2}{|c|}{ 1) The output information is reliable. } \\
\hline \multicolumn{2}{|l|}{ 1: Strongly low 5 _. Strongly high } \\
\hline Innovative capability & (Wang et al., 2015) \\
\hline \multicolumn{2}{|c|}{ Compared with your major competitors, how good is your organization's capability in the following areas: } \\
\hline \multicolumn{2}{|c|}{ 1) To innovate on business and managerial processes } \\
\hline \multicolumn{2}{|c|}{ 1) To make continuous improvement on product and service quality } \\
\hline \multicolumn{2}{|c|}{ 1) To develop and adopt new technologies that enhance market offerings } \\
\hline \multicolumn{2}{|c|}{ 1) To develop new products and services with cutting edge technology } \\
\hline \multicolumn{2}{|c|}{ 1: Much weaker 5 _.: Much stronger } \\
\hline Firm agility & (Tallon \& Pinsonneault, 2011) \\
\hline \multicolumn{2}{|c|}{$\begin{array}{l}\text { Compared with your major competitors, how easily and quickly can your organization perform in the } \\
\text { following activities: }\end{array}$} \\
\hline \multicolumn{2}{|c|}{ 1) Respond to changes in aggregate consumer demand } \\
\hline 1) Customize a product or service & \\
\hline 1) React to new product or service & \\
\hline 1) Introduce new pricing schedule & \\
\hline 1) Expand into new regional or int & \\
\hline 1) Change (i.e., expand or reduce) & \\
\hline 1) Adopt new technologies to prod & \\
\hline 1) Switch suppliers to avail of low & \\
\hline 1: Much weaker 5 __: Much stronger & \\
\hline Technological turbulence & (Pavlou \& El Sawy, 2010) \\
\hline To what extent do you agree with $t$ & \\
\hline 1) The technology in this product & \\
\hline 1) Technological breakthroughs pr & \\
\hline 1: Strongly disagree 5 __. Strongly ag & \\
\hline Market turbulence & (Pavlou \& El Sawy, 2010) \\
\hline To what extent do you agree with $t$ & \\
\hline 1) In our kind of business, custom & \\
\hline 1) Marketing practices in our prod & \\
\hline 1) New product introductions are & \\
\hline 1: Strongly disagree 5 _.: Strongly ag & \\
\hline Firm performance & (Chen et al., 2014) \\
\hline $\begin{array}{l}\text { Compared with your major competi } \\
\text { the last } 2 \text { or } 3 \text { years: }\end{array}$ & \\
\hline 1) Return on Investments & \\
\hline 1) Market share & \\
\hline 1) Sales growth & \\
\hline 1) Overall profitability & \\
\hline 1: Much weaker 5 _.: Much stronger & \\
\hline
\end{tabular}




\section{Appendix B}

Table B1.

Table B1

Reliability of constructs.

\begin{tabular}{|c|c|c|c|c|}
\hline Constructs & Loadings & $\begin{array}{l}\text { Average } \\
\text { Variance } \\
\text { Extracted } \\
\text { (AVE) }\end{array}$ & $\begin{array}{l}\text { Composite } \\
\text { Reliability }\end{array}$ & $\begin{array}{l}\text { Cronbach's } \\
\text { Alpha }\end{array}$ \\
\hline BA capabilities & & 0.77 & 0.94 & 0.93 \\
\hline AC01 & 0.93 & & & \\
\hline $\mathrm{ACO} 2$ & 0.85 & & & \\
\hline $\mathrm{ACO} 3$ & 0.85 & & & \\
\hline $\mathrm{ACO} 4$ & 0.87 & & & \\
\hline AC05 & 0.88 & & & \\
\hline Information quality & & 0.68 & 0.92 & 0.85 \\
\hline IQ01 & 0.85 & & & \\
\hline IQ02 & 0.92 & & & \\
\hline IQ03 & 0.80 & & & \\
\hline IQ04 & 0.77 & & & \\
\hline IQ05 & 0.78 & & & \\
\hline $\begin{array}{l}\text { Innovative } \\
\text { capability }\end{array}$ & & 0.64 & 0.88 & 0.84 \\
\hline IC01 & 0.79 & & & \\
\hline IC02 & 0.77 & & & \\
\hline IC03 & 0.83 & & & \\
\hline ICO4 & 0.81 & & & \\
\hline Firm agility & & 0.66 & 0.94 & 0.88 \\
\hline OA01 & 0.80 & & & \\
\hline OA02 & 0.83 & & & \\
\hline OA03 & 0.84 & & & \\
\hline OA04 & 0.79 & & & \\
\hline OA05 & 0.71 & & & \\
\hline OA06 & 0.79 & & & \\
\hline OA07 & 0.82 & & & \\
\hline OA08 & 0.89 & & & \\
\hline $\begin{array}{l}\text { Technological } \\
\text { turbulence }\end{array}$ & & 0.71 & 0.83 & 0.76 \\
\hline TT01 & 0.83 & & & \\
\hline TT02 & 0.85 & & & \\
\hline Market turbulence & & 0.72 & 0.88 & 0.82 \\
\hline MT01 & 0.86 & & & \\
\hline MT02 & 0.80 & & & \\
\hline MT03 & 0.88 & & & \\
\hline Firm performance & & 0.60 & 0.85 & 0.78 \\
\hline FP01 & 0.85 & & & \\
\hline FP02 & 0.70 & & & \\
\hline FP03 & 0.72 & & & \\
\hline FP04 & 0.81 & & & \\
\hline
\end{tabular}

\section{References}

Abbasi, A., Sarker, S., \& Chiang, R. H. (2016). Big data research in information systems: Toward an inclusive research agenda. Journal of the Association for Information Systems, 17(2), 1-32.

Abdolvand, N., \& Sepehri, M. M. (2016). Antecedents of strategic information systems alignment in Iran. Journal of Global Information Technology Management, 19(2), 80-103.

Akter, S., Fosso Wamba, S., Gunasekaran, A., Dubey, R., \& Childe, S. J. (2016). How to improve firm performance using big data analytics capability and business strategy alignment? International Journal of Production Economics, 182, 113-131.

Alaeddini, M., \& Salekfard, S. (2013). Investigating the role of an enterprise architecture project in the business-IT alignment in Iran. Information Systems Frontiers, 15(1), $67-88$.

Albadvi, A., Keramati, A., \& Razmi, J. (2007). Assessing the impact of information technology on firm performance considering the role of intervening variables: Organizational infrastructures and business processes reengineering. International Journal of Production Research, 45(12), 2697-2734.
Alolah, T., Stewart, R. A., Panuwatwanich, K., \& Mohamed, S. (2014). Determining the causal relationships among balanced scorecard perspectives on school safety performance: Case of Saudi Arabia. Accident Analysis \& Prevention, 68, 57-74.

Arunachalam, D., Kumar, N., \& Kawalek, J. P. (2018). Understanding big data analytics capabilities in supply chain management: Unravelling the issues, challenges and implications for practice. Transportation Research Part E: Logistics and Transportation Review, 114, 416-436.

Ashrafi, A., \& Zare Ravasan, A. (2018). How market orientation contributes to innovation and market performance: The roles of business analytics and flexible IT infrastructure. Journal of Business \& Industrial Marketing, 33(7), 970-983.

Bayo-Moriones, A., \& Lera-López, F. (2007). A firm-level analysis of determinants of ICT adoption in Spain. Technovation, 27(6), 352-366.

Becker, T. E., Atinc, G., Breaugh, J. A., Carlson, K. D., Edwards, J. R., \& Spector, P. E. (2016). Statistical control in correlational studies: 10 essential recommendations for organizational researchers. Journal of Organizational Behavior, 37(2), 157-167.

Bernerth, J. B., \& Aguinis, H. (2016). A critical review and best-practice recommendations for control variable usage. Personnel Psychology, 69(1), 229-283.

Bertsimas, D., Bradlow, E., Gans, N., \& Gupta, A. (2014). Introduction to the special issue on business analytics. Management Science, 60(6), 1351. 
Bharadwaj, A. S. (2000). A resource-based perspective on information technology capability and firm performance: An empirical investigation. MIS Quarterly, 24(1), 169-196.

Bhatt, G., Emdad, A., Roberts, N., \& Grover, V. (2010). Building and leveraging in formation in dynamic environments: The role of IT infrastructure flexibility as enabler of organizational responsiveness and competitive advantage. Information \& Management, 47(7), 341-349.

Bichler, M., Heinzl, A., \& van der Aalst, W. M. (2017). Business Analytics and Data Science: Once Again? Business \& Information Systems Engineering 59(2), 77-79.

Bose, R. (2009). Advanced analytics: Opportunities and challenges. Industrial Management \& Data Systems, 109(2), 155-172.

Brynjolfsson, E., Hitt, L. M., \& Kim, H. H. (2011). Strength in numbers: How does data-driven decision making affect firm performance?, Working paper. Cambridge, MA: Sloan School of Management, MIT April 222011.

Cadez, S., \& Guilding, C. (2008). An exploratory investigation of an integrated contingency model of strategic management accounting. Accounting Organizations and Society, 33(7), 836-863.

Calantone, R. J., Cavusgil, S. T., \& Zhao, Y. (2002). Learning orientation, firm innovation capability, and firm performance. Industrial Marketing Management, 31(6), 515-524.

Cao, G., Duan, Y., \& Cadden, T. (2019). The link between information processing capability and competitive advantage mediated through decision-making effectiveness. International Journal of Information Management, 44, 121-131.

Cao, G., Duan, Y., \& Li, G. (2015). Linking business analytics to decision making effectiveness: A path model analysis. IEEE Transactions on Engineering Management, 62(3), 384-395.

Chae, B. K. (2014). A complexity theory approach to IT-enabled services (IESs) and service innovation: Business analytics as an illustration of IES. Decision Support Systems, $57,1-10$.

Chae, B. K., Yang, C., Olson, D., \& Sheu, C. (2014). The impact of advanced analytics and data accuracy on operational performance: A contingent resource based theory (RBT) perspective. Decision Support Systems, 59, 119-126.

Chakravarty, A., Grewal, R., \& Sambamurthy, V. (2013). Information technology competencies, organizational agility, and firm performance: Enabling and facilitating roles. Information Systems Research, 24(4), 976-997.

Chen, C.-J. (2018). Developing a model for supply chain agility and innovativeness to enhance firms' competitive advantage. Management Decision. https://doi.org/10. 1108/MD-12-2017-1236.

Chen, H., Chiang, R. H., \& Storey, V. C. (2012). Business intelligence and analytics: From big data to big impact. MIS Quarterly, 36(4), 1165-1188.

Chen, J., Neubaum, D. O., Reilly, R. R., \& Lynn, G. S. (2015). The relationship between team autonomy and new product development performance under different levels of technological turbulence. Journal of Operations Management, 33, 83-96.

Chen, Y.-S., Lin, M.-J. J., \& Chang, C.-H. (2009). The positive effects of relationship learning and absorptive capacity on innovation performance and competitive advantage in industrial markets. Industrial Marketing Management, 38(2), 152-158.

Chen, Y., Wang, Y., Nevo, S., Jin, J., Wang, L., \& Chow, W. S. (2014). IT capability and organizational performance: The roles of business process agility and environmental factors. European Journal of Information Systems, 23(3), 326-342.

Chung, W., \& Tseng, T.-L. B. (2012). Discovering business intelligence from online product reviews: A rule-induction framework. Expert Systems With Applications, 39(15) $11870-11879$.

Cimperman, M., Brenčič, M. M., \& Trkman, P. (2016). Analyzing older users' home telehealth services acceptance behavior-Applying an Extended UTAUT model International Journal of Medical Informatics, 90, 22-31.

Cohen, J. (1988). Statistical power analysis for the behavioral sciences (2nd edn.). New York: Routledge: Erlbaum Associates, Hillsdale p. 567 pages.

Cohen, J. (1992). Quantitative methods in psychology: A power primer. Psychological Bulletin, 112, 1155-1159.

Côrte-Real, N., Oliveira, T., \& Ruivo, P. (2017). Assessing business value of Big Data Analytics in European firms. Journal of Business Research, 70(1), 379-390.

Davenport, T. H., \& Harris, J. G. (2007). Competing on analytics: The new science of winning. Harvard Business Press.

DeGroote, S. E., \& Marx, T. G. (2013). The impact of IT on supply chain agility and firm performance: An empirical investigation. International Journal of Information Management, 33(6), 909-916.

Delen, D., \& Demirkan, H. (2013). Data, information and analytics as services. Decision Support Systems, 55(1), 359-363.

Delone, W. H., \& McLean, E. R. (2003). The DeLone and McLean model of information systems success: a ten-year update. Journal of Management Information Systems, 19(4), 9-30.

Devaraj, S., \& Kohli, R. (2003). Performance impacts of information technology: Is actual usage the missing link? Management Science, 49(3), 273-289.

Donya-e-Eghtesad (2016). Top 500 companies of Iran, Donya-e-Eghtesad newspaper. Available from . Accessed in April 2016 [In Persian] goo.gl/p19b87.

Dove, R. (2001). Response ability: The language, structure, and culture of the agile enterprise. John Wiley \& Sons.

Dubey, R., Ali, S. S., Aital, P., \& Venkatesh, V. (2014). Mechanics of humanitarian supply chain agility and resilience and its empirical validation. International Journal of Services and Operations Management, 17(4), 367-384.

Dubey, R., Gunasekaran, A., Childe, S. J., Wamba, S. F., \& Papadopoulos, T. (2016). The impact of big data on world-class sustainable manufacturing. The International Journal of Advanced Manufacturing Technology, 84(1), 631-645.

Dubey, R., Altay, N., Gunasekaran, A., Blome, C., Papadopoulos, T., \& Childe, S. J. (2018). Supply chain agility, adaptability and alignment: empirical evidence from the Indian auto components industry. International Journal of Operations \& Production Management, 38(1), 129-148.
Dubey, R., Gunasekaran, A., Childe, S. J., Papadopoulos, T., Luo, Z., Wamba, S. F., et al. (2018). Can big data and predictive analytics improve social and environmental sustainability? Technological Forecasting and Social Change. https://doi.org/10.1016/j. techfore.2017.06.020 In press.

Dubey, R., Gunasekaran, A., \& Childe, S. J. (2018). Big data analytics capability in supply chain agility: The moderating effect of organizational flexibility. Management Decision. https://doi.org/10.1108/MD-01-2018-0119.

Dutta, A., Lee, H., \& Yasai-Ardekani, M. (2014). Digital systems and competitive responsiveness: The dynamics of IT business value. Information \& Management, 51(6), 762-773.

Elbashir, M. Z., Collier, P. A., \& Davern, M. J. (2008). Measuring the effects of business intelligence systems: The relationship between business process and organizational performance. International Journal of Accounting Information Systems, 9(3), 135-153.

Esterhuizen, D., Schutte, C., \& Du Toit, A. (2012). Knowledge creation processes as critical enablers for innovation. International Journal of Information Management, 32(4), 354-364.

Fassott, G., Henseler, J., \& Coelho, P. S. (2016). Testing moderating effects in PLS path models with composite variables. Industrial Management \& Data Systems, 116(9), 1887-1900.

Fink, L., Yogev, N., \& Even, A. (2017). Business intelligence and organizational learning: An empirical investigation of value creation processes. Information \& Management, 54(1), 38-56.

Flynn, B. B., Sakakibara, S., Schroeder, R. G., Bates, K. A., \& Flynn, E. J. (1990). Empirical research methods in operations management. Journal of Operations Management, 9(2), 250-284.

Fosso Wamba, S., Akter, S., Edwards, A., Chopin, G., \& Gnanzou, D. (2015). How 'big data'can make big impact: Findings from a systematic review and a longitudinal case study. International Journal of Production Economics, 165, 234-246.

Fosso Wamba, S., Gunasekaran, A., Akter, S., Ren, S. J.-f., Dubey, R., \& Childe, S. J. (2017). Big data analytics and firm performance: Effects of dynamic capabilities. Journal of Business Research, 70, 356-365.

Fosso Wamba, S., Ngai, E. W., Riggins, F., \& Akter, S. (2017). Guest editorial: Transforming operations and production management using big data and business analytics: Future research directions. International Journal of Operations and Production, 37(1), 2-9.

Gandomi, A., \& Haider, M. (2015). Beyond the hype: Big data concepts, methods, and analytics. International Journal of Information Management, 35(2), 137-144.

Ganguly, A., Nilchiani, R., \& Farr, J. V. (2009). Evaluating agility in corporate enterprises. International Journal of Production Economics, 118(2), 410-423.

Germann, F., Lilien, G. L., \& Rangaswamy, A. (2013). Performance implications of deploying marketing analytics. International Journal of Research in Marketing, 30(2), 114-128.

Ghasemaghaei, M., Hassanein, K., \& Turel, O. (2017). Increasing firm agility through the use of data analytics: The role of fit. Decision Support Systems, 101, 95-105.

Gligor, D. M., Esmark, C. L., \& Holcomb, M. C. (2015). Performance outcomes of supply chain agility: When should you be agile? Journal of Operations Management, 33-34, 71-82.

Gunasekaran, A., Papadopoulos, T., Dubey, R., Wamba, S. F., Childe, S. J., Hazen, B., et al (2017). Big data and predictive analytics for supply chain and organizational performance. Journal of Business Research, 70, 308-317.

Gunday, G., Ulusoy, G., Kilic, K., \& Alpkan, L. (2011). Effects of innovation types on firm performance. International Journal of Production Economics, 133(2), 662-676.

Gupta, M., \& George, J. F. (2016). Toward the development of a big data analytics capability. Information \& Management, 53(8), 1049-1064.

Gustavsson, M., \& Jonsson, P. (2008). Perceived quality deficiencies of demand information and their consequences. International Journal of Logistics Research and Applications, 11(4), 295-312.

Hair, J. J. F., Hult, G. T. M., Ringle, C., \& Sarstedt, M. (2017). A primer on partial least squares structural equation modeling (PLS-SEM). Sage Publications.

Hanafizadeh, P., \& Zare Ravasan, A. (2018). An empirical analysis on outsourcing decision: The case of e-banking services. Journal of Enterprise Information Management, 31(1), 146-172.

Henseler, J., Dijkstra, T. K., Sarstedt, M., Ringle, C. M., Diamantopoulos, A., Straub, D. W., et al. (2014). Common beliefs and reality about PLS: Comments on Rönkkö and Evermann (2013). Organizational Research Methods, 17(2), 182-209.

Henseler, J., Hubona, G., \& Ray, P. A. (2016). Using PLS path modeling in new technology research: Updated guidelines. Industrial Management \& Data Systems, 116(1), 2-20.

Henseler, J., Ringle, C. M., \& Sarstedt, M. (2015). A new criterion for assessing discriminant validity in variance-based structural equation modeling. Journal of the Academy of Marketing Science, 43(1), 115-135.

Hitt, M. A., Keats, B. W., \& DeMarie, S. M. (1998). Navigating in the new competitive landscape: Building strategic flexibility and competitive advantage in the 21st century. The Academy of Management Executive, 12(4), 22-42.

Holsapple, C., Lee-Post, A., \& Pakath, R. (2014). A unified foundation for business analytics. Decision Support Systems, 64, 130-141.

Howson, C. (2007). Successful business intelligence. Tata McGraw-Hill Education.

Huang, P.-Y., Pan, S. L., \& Ouyang, T. H. (2014). Developing information processing capability for operational agility: Implications from a Chinese manufacturer. European Journal of Information Systems, 23(4), 462-480.

Hung, K.-P., \& Chou, C. (2013). The impact of open innovation on firm performance: The moderating effects of internal R\&D and environmental turbulence. Technovation, 33(10), 368-380.

Issk, Ö., Jones, M. C., \& Sidorova, A. (2013). Business intelligence success: The roles of BI capabilities and decision environments. Information \& Management, 50(1), 13-23.

Jaklič, J., Grublješič, T., \& Popovič, A. (2018). The role of compatibility in predicting business intelligence and analytics use intentions. International Journal of Information 
Management, 43, 305-318.

Jaworski, B. J., \& Kohli, A. K. (1993). Market orientation: Antecedents and consequences. The Journal of Marketing, 57(3), 53-70.

Jeble, S., Dubey, R., Childe, S. J., Papadopoulos, T., Roubaud, D., \& Prakash, A. (2018). Impact of big data and predictive analytics capability on supply chain sustainability. The International Journal of Logistics Management, 29(2), 513-538.

Ji-fan Ren, S., Fosso Wamba, S., Akter, S., Dubey, R., \& Childe, S. J. (2017). Modelling quality dynamics, business value and firm performance in a big data analytics environment. International Journal of Production Research, 55(17), 5011-5026.

Judge, W. Q., \& Elenkov, D. (2005). Organizational capacity for change and environmental performance: An empirical assessment of Bulgarian firms. Journal of Business Research, 58(7), 893-901.

Keramati, A., Mehrabi, H., \& Mojir, N. (2010). A process-oriented perspective on customer relationship management and organizational performance: An empirical investigation. Industrial Marketing Management, 39(7), 1170-1185.

Kiron, D., \& Shockley, R. (2011). Creating business value with analytics. MIT sloan management review, 53(1), 57.

Kitchens, B., Dobolyi, D., Li, J., \& Abbasi, A. (2018). Advanced customer analytics: Strategic value through integration of relationship-oriented big data. Journal of Management Information Systems, 35(2), 540-574.

Kock, A., \& Georg Gemünden, H. (2016). Antecedents to decision-making quality and agility in innovation portfolio management. Journal of Product Innovation Management, 33(6), 670-686.

Kowalczyk, M., \& Buxmann, P. (2015). An ambidextrous perspective on business intelligence and analytics support in decision processes: Insights from a multiple case study. Decision Support Systems, 80, 1-13.

Kwon, O., Lee, N., \& Shin, B. (2014). Data quality management, data usage experience and acquisition intention of big data analytics. International Journal of Information Management, 34(3), 387-394.

Larson, D., \& Chang, V. (2016). A review and future direction of agile, business intelligence, analytics and data science. International Journal of Information Management, 36(5), 700-710.

Laursen, G. H., \& Thorlund, J. (2010). Business analytics for managers: Taking business intelligence beyond reporting. John Wiley \& Sons.

LaValle, S., Hopkins, M. S., Lesser, E., Shockley, R., \& Kruschwitz, N. (2010). Analytics: The new path to value. MIT sloan management review, 52(1), 1-25.

Leal-Rodríguez, A. L., Roldán, J. L., Ariza-Montes, J. A., \& Leal-Millán, A. (2014). From potential absorptive capacity to innovation outcomes in project teams: The conditional mediating role of the realized absorptive capacity in a relational learning context. International Journal of Project Management, 32(6), 894-907.

Lee, O.-K., Sambamurthy, V., Lim, K. H., \& Wei, K. K. (2015). How does IT ambidexterity impact organizational agility? Information Systems Research, 26(2), 398-417.

Li, S., \& Lin, B. (2006). Accessing information sharing and information quality in supply chain management. Decision Support Systems, 42(3), 1641-1656.

Lismont, J., Vanthienen, J., Baesens, B., \& Lemahieu, W. (2017). Defining analytics maturity indicators: A survey approach. International Journal of Information Management, $37(3), 114-124$.

Liu, H., Ke, W., Wei, K. K., \& Hua, Z. (2013). The impact of IT capabilities on firm per formance: The mediating roles of absorptive capacity and supply chain agility. Decision Support Systems, 54(3), 1452-1462.

Lohmöller, J.-B. (1989). Predictive vs. structural modeling: Pls vs. ml, Latent Variable Path Modeling with Partial Least Squares. Springer199-226.

Lu, Y., \& Ramamurthy, K. (2011). Understanding the link between information technology capability and organizational agility: An empirical examination. MIS Quarterly, 35(7), 931-954.

Malhotra, N. K., Schaller, T. K., \& Patil, A. (2017). Common method variance in advertising research: When to be concerned and how to control for it. Journal of Advertising, 46(1), 193-212.

March, S. T., \& Hevner, A. R. (2007). Integrated decision support systems: A data warehousing perspective. Decision Support Systems, 43(3), 1031-1043.

Melville, N., Kraemer, K., \& Gurbaxani, V. (2004). Review: Information technology and organizational performance: An integrative model of IT business value. MIS Quarterly, 28(2), 283-322.

Mithas, S., Ramasubbu, N., \& Sambamurthy, V. (2011). How information management capability influences firm performance. MIS Quarterly, 35(1), 237-256.

Nam, D., Lee, J., \& Lee, H. (2018). Business analytics use in CRM: a nomological net from IT competence to CRM performance. International Journal of Information Management. https://doi.org/10.1016/j.ijinfomgt.2018.01.005.

Nevo, S., \& Wade, M. R. (2010). The formation and value of IT-enabled resources: Antecedents and consequences of synergistic relationships. MIS Quarterly, 34(1), 163-183.

Newman, D., \& Logan, D. (2006). Achieving agility: How enterprise information management overcomes information silos. Stamford, CT: Gartner Research.

Oh, W., \& Pinsonneault, A. (2007). On the assessment of the strategic value of information technologies: Conceptual and analytical approaches. MIS Quarterly, 31(2), 239-265.

Olszak, C. M. (2016). Toward better understanding and use of Business Intelligence in organizations. Information Systems Management, 33(2), 105-123.

Overby, E., Bharadwaj, A., \& Sambamurthy, V. (2006). Enterprise agility and the enabling role of information technology. European Journal of Information Systems, 15(2), 120-131.

Pavlou, P. A., \& El Sawy, O. A. (2010). The "third hand": IT-enabled competitive advantage in turbulence through improvisational capabilities. Information Systems Research, 21(3), 443-471.

Peters, M. D., Wieder, B., Sutton, S. G., \& Wakefield, J. (2016). Business intelligence systems use in performance measurement capabilities: Implications for enhanced competitive advantage. International Journal of Accounting Information Systems, 21,
$1-17$.

Petter, S., DeLone, W., \& McLean, E. (2008). Measuring information systems success: Models, dimensions, measures, and interrelationships. European Journal of Information Systems, 17(3), 236-263.

Podsakoff, P. M., MacKenzie, S. B., \& Podsakoff, N. P. (2012). Sources of method bias in social science research and recommendations on how to control it. Annual Review of Psychology, 63, 539-569.

Popovic, A., \& Habjan, A. (2012). Exploring the effects of information quality change in road transport operations. Industrial Management \& Data Systems, 112(9), 1307-1325.

Popovič, A., Hackney, R., Coelho, P. S., \& Jaklič, J. (2012). Towards business intelligence systems success: Effects of maturity and culture on analytical decision making. Decision Support Systems, 54(1), 729-739.

Popovič, A., Hackney, R., Coelho, P. S., \& Jaklič, J. (2014). How information-sharing values influence the use of information systems: An investigation in the business intelligence systems context. The Journal of Strategic Information Systems, 23(4), 270-283.

Popovič, A., Hackney, R., Tassabehji, R., \& Castelli, M. (2018). The impact of big data analytics on firms' high value business performance. Information Systems Frontiers, 20(2), 209-222.

Puklavec, B., Oliveira, T., \& Popovič, A. (2018). Understanding the determinants of business intelligence system adoption stages: An empirical study of SMEs. Industrial Management \& Data Systems, 118(1), 236-261.

Rai, A., Patnayakuni, R., \& Seth, N. (2006). Firm performance impacts of digitally enabled supply chain integration capabilities. MIS Quarterly, 30(2), 225-246.

Ramakrishnan, T., Jones, M. C., \& Sidorova, A. (2012). Factors influencing business intelligence (BI) data collection strategies: An empirical investigation. Decision Support Systems, 52(2), 486-496.

Ramanathan, R., Philpott, E., Duan, Y., \& Cao, G. (2017). Adoption of business analytics and impact on performance: A qualitative study in retail. Production Planning \& Control, 28(11-12), 985-998.

Raschke, R. L. (2010). Process-based view of agility: The value contribution of IT and the effects on process outcomes. International Journal of Accounting Information Systems, 11(4), 297-313.

Richter, N. F., Cepeda, G., Roldán, J. L., \& Ringle, C. M. (2016). European management research using partial least squares structural equation modeling (PLS-SEM). European Management Journal, 34(6), 589-597.

C.M.S. Ringle Wende , J.-M. Becker , SmartPLS 3. Boenningstedt SmartPLS GmbH 2015; http://www.smartpls.com.

Rivard, S. (2014). Editor's comments: The ions of theory construction. MIS Quarterly, 38(2) iii-xiv.

Roberts, N., \& Grover, V. (2012). Investigating firm's customer agility and firm performance: The importance of aligning sense and respond capabilities. Journal of Business Research, 65(5), 579-585.

Roden, S., Nucciarelli, A., Li, F., \& Graham, G. (2017). Big data and the transformation of operations models: A framework and a new research agenda. Production Planning \& Control, 28(11-12), 929-944.

Rosenbusch, N., Brinckmann, J., \& Bausch, A. (2011). Is innovation always beneficial? A meta-analysis of the relationship between innovation and performance in SMEs. Journal of Business Venturing, 26(4), 441-457.

Rouhani, S., Ashrafi, A., Ravasan, A. Z., \& Afshari, S. (2018). Business intelligence systems adoption model: An empirical investigation. Journal of Organizational and End User Computing (JOEUC), 30(2), 43-70.

Rouhani, S., Ashrafi, A., Zare Ravasan, A., \& Afshari, S. (2016). The impact model of business intelligence on decision support and organizational benefits. Journal of Enterprise Information Management, 29(1), 19-50.

Rud, O. P. (2009). Business intelligence success factors: Tools for aligning your business in the global economy. John Wiley \& Sons.

Rungtusanatham, M. J., Choi, T. Y., Hollingworth, D. G., Wu, Z., \& Forza, C. (2003). Survey research in operations management: Historical analyses. Journal of Operations Management, 21(4), 475-488.

Sahay, B., \& Ranjan, J. (2008). Real time business intelligence in supply chain analytics. Information Management \& Computer Security, 16(1), 28-48.

Sambamurthy, V., Bharadwaj, A., \& Grover, V. (2003). Shaping agility through digital options: Reconceptualizing the role of information technology in contemporary firms. MIS Quarterly, 27(2), 237-263.

Sangari, M. S., \& Razmi, J. (2015). Business intelligence competence, agile capabilities, and agile performance in supply chain: An empirical study. The International Journal of Logistics Management, 26(2), 356-380.

Santiago Rivera, D., \& Shanks, G. (2015). A dashboard to support management of business analytics capabilities. Journal of Decision Systems, 24(1), 73-86.

Seddon, P. B., Constantinidis, D., Tamm, T., \& Dod, H. (2017). How does business analytics contribute to business value? Information Systems Journal, 27(3), 237-269.

Seo, D., \& La Paz, A. I. (2008). Exploring the dark side of IS in achieving organizational agility. Communications of the ACM, 51(11), 136-139.

Sharma, R., Mithas, S., \& Kankanhalli, A. (2014). Transforming decision-making processes: a research agenda for understanding the impact of business analytics on organisations. European Journal of Information Systems, 23(4), 433-441.

Shen, C.-C., Chang, R.-E., Hsu, C. J., \& Chang, I.-C. (2017). How business intelligence maturity enabling hospital agility. Telematics and Informatics, 34(1), 450-456.

Sherehiy, B., Karwowski, W., \& Layer, J. K. (2007). A review of enterprise agility: Concepts, frameworks, and attributes. International Journal of Industrial Ergonomics, 37(5), 445-460.

Shollo, A., \& Galliers, R. D. (2016). Towards an understanding of the role of business intelligence systems in organisational knowing. Information Systems Journal, 26(4), 339-367.

Sivarajah, U., Kamal, M. M., Irani, Z., \& Weerakkody, V. (2017). Critical analysis of Big 
Data challenges and analytical methods. Journal of Business Research, 70, 263-286.

Slater, S. F., \& Narver, J. C. (1994). Does competitive environment moderate the market orientation-performance relationship? Journal of Marketing, 58, 46-55.

Someh, I. A., \& Shanks, G. G. (2015). How business analytics systems provide benefits and contribute to firm performance? ECIS.

Son, I., Lee, D., Lee, J.-N., \& Chang, Y. B. (2014). Market perception on cloud computing initiatives in organizations: An extended resource-based view. Information \& Management, 51(6), 653-669.

Song, Z.-h. (2015). Organizational learning, absorptive capacity, imitation and innovation: Empirical analyses of 115 firms across China. Chinese Management Studies, 9(1), 97-113.

Stieglitz, S., Mirbabaie, M., Ross, B., \& Neuberger, C. (2018). Social media analytics-Challenges in topic discovery, data collection, and data preparation. International Journal of Information Management, 39, 156-168.

Stoel, M. D., \& Muhanna, W. A. (2009). IT capabilities and firm performance: A contingency analysis of the role of industry and IT capability type. Information \& Management, 46(3), 181-189.

R, S., \& Leroi-Werelds, S. (2016). Bootstrapping and PLS-SEM: A step-by-step guide to get more out of your bootstrap results. European Management Journal, 34(6), 618-632.

Subramani, M. (2004). How do suppliers benefit from information technology use in supply chain relationships? MIS Quarterly, 28(1), 45-73.

Swafford, P. M., Ghosh, S., \& Murthy, N. (2008). Achieving supply chain agility through IT integration and flexibility. International Journal of Production Economics, 116(2), 288-297.

Tallon, P. P., \& Pinsonneault, A. (2011). Competing perspectives on the link between strategic information technology alignment and organizational agility: Insights from a mediation model. MIS Quarterly, 35(2), 463-486.

Tamer Cavusgil, S., Calantone, R. J., \& Zhao, Y. (2003). Tacit knowledge transfer and firm innovation capability. Journal of Business and Industrial Marketing, 18(1), 6-21.

Tan, F. T. C., Tan, B., Wang, W., \& Sedera, D. (2017). IT-enabled operational agility: An interdependencies perspective. Information \& Management, 54(3), 292-303.

Teece, D., Peteraf, M., \& Leih, S. (2016). Dynamic capabilities and organizational agility. California Management Review, 58(4), 13-35.

Teece, D. J., Pisano, G., \& Shuen, A. (1997). Dynamic capabilities and strategic management. Strategic Management Journal, 18(7), 509-533.

Teo, T. S., Nishant, R., \& Koh, P. B. (2016). Do shareholders favor business analytics announcements? The Journal of Strategic Information Systems, 25(4), 259-276.

Tippins, M. J., \& Sohi, R. S. (2003). IT competency and firm performance: is organizational learning a missing link? Strategic Management Journal, 24(8), 745-761.

Torres, R., Sidorova, A., \& Jones, M. C. (2018). Enabling firm performance through business intelligence and analytics: A dynamic capabilities perspective. Information \& Management, 55(7), 822-839.

Trieu, V.-H. (2017). Getting value from Business Intelligence systems: A review and research agenda. Decision Support Systems, 93, 111-124.

Trinh-Phuong, T., Molla, A., \& Peszynski, K. (2012). Enterprise systems and organizational agility: A review of the literature and conceptual framework. Communications of the Association for Information Systems, 31(1), 167-192.

Trkman, P., \& McCormack, K. (2009). Supply chain risk in turbulent environments-A conceptual model for managing supply chain network risk. International Journal of Production Economics, 119(2), 247-258.

Trkman, P., Budler, M., Groznik, A., \& Wagner, B. (2015). A business model approach to supply chain management. Supply Chain Management: An International Journal, 20(6), 587-602.

Trkman, P., McCormack, K., De Oliveira, M. P. V., \& Ladeira, M. B. (2010). The impact of business analytics on supply chain performance. Decision Support Systems, 49(3), 318-327.

Troilo, M., Bouchet, A., Urban, T. L., \& Sutton, W. A. (2016). Perception, reality, and the adoption of business analytics: Evidence from North American professional sport organizations. Omega, 59, 72-83.

van Oosterhout, M., Waarts, E., \& van Hillegersberg, J. (2006). Change factors requiring agility and implications for IT. European Journal of Information Systems, 15(2), $132-145$.
Venkatraman, N., \& Ramanujam, V. (1986). Measurement of business performance in strategy research: A comparison of approaches. The Academy of Management Review, 11(4), 801-814.

Viaene, S., \& Van den Bunder, A. (2011). The secrets to managing business analytics projects. MIT sloan management review, 53(1), 65-69.

Vidgen, R., Shaw, S., \& Grant, D. B. (2017). Management challenges in creating value from business analytics. European Journal of Operational Research, 261(2), 626-639.

Wade, M., \& Hulland, J. (2004). Review: The resource-based view and information systems research: Review, extension, and suggestions for future research. MIS Quarterly, 28(1), 107-142.

Wagner, H.-T., Beimborn, D., \& Weitzel, T. (2014). How social capital among information technology and business units drives operational alignment and IT business value. Journal of Management Information Systems, 31(1), 241-272.

Wang, X., \& Dass, M. (2017). Building innovation capability: The role of top management innovativeness and relative-exploration orientation. Journal of Business Research, 76, $127-135$.

Wang, G., Dou, W., Zhu, W., \& Zhou, N. (2015). The effects of firm capabilities on external collaboration and performance: The moderating role of market turbulence. Journal of Business Research, 68(9), 1928-1936.

Wang, Y., Chen, Y., Nevo, S., Jin, J., Tang, G., \& Chow, W. (2013). IT capabilities and innovation performance: The mediating role of market orientation. Communications of the Association for Information Systems, 33(1), 129-148.

Wang, Y., Kung, L., \& Byrd, T. A. (2018). Big data analytics: Understanding its capabilities and potential benefits for healthcare organizations. Technological Forecasting and Social Change, 126, 3-13.

Wang, Y., Kung, L., Wang, W. Y. C., \& Cegielski, C. G. (2018). An integrated big data analytics-enabled transformation model: Application to health care. Information \& Management, 55(1), 64-79.

Winby, S., \& Worley, C. G. (2014). Management processes for agility, speed, and in novation. Organizational Dynamics, 3(43), 225-234.

Xu, Z., Frankwick, G. L., \& Ramirez, E. (2016). Effects of big data analytics and traditional marketing analytics on new product success: A knowledge fusion perspective. Journal of Business Research, 69(5), 1562-1566.

Yauch, C. A. (2011). Measuring agility as a performance outcome. Journal of Manufacturing Technology Management, 22(3), 384-404.

Yayla, A. A., \& Hu, Q. (2012). The impact of IT-business strategic alignment on firm performance in a developing country setting: Exploring moderating roles of environmental uncertainty and strategic orientation. European Journal of Information Systems, 21(4), 373-387.

Yeoh, W., \& Popovič, A. (2016). Extending the understanding of critical success factors for implementing business intelligence systems. Journal of the Association for Information Science and Technology, 67(1), 134-147.

Yu, Y., Dong, X.-Y., Shen, K. N., Khalifa, M., \& Hao, J.-X. (2013). Strategies, technologies, and organizational learning for developing organizational innovativeness in emerging economies. Journal of Business Research, 66(12), 2507-2514.

Yusuf, Y. Y., Gunasekaran, A., Musa, A., Dauda, M., El-Berishy, N. M., \& Cang, S. (2014). A relational study of supply chain agility, competitiveness and business performance in the oil and gas industry. International Journal of Production Economics, 147 531-543.

Zain, M., Rose, R. C., Abdullah, I., \& Masrom, M. (2005). The relationship between information technology acceptance and organizational agility in Malaysia. Information \& Management, 42(6), 829-839.

Zare Ravasan, A., \& Mansouri, T. (2016). A dynamic ERP critical failure factors modelling with FCM throughout project lifecycle phases. Production Planning \& Control, 27(2), 65-82.

Zhang, C., \& Dhaliwal, J. (2009). An investigation of resource-based and institutional theoretic factors in technology adoption for operations and supply chain management. International Journal of Production Economics, 120(1), 252-269.

Zhou, J., Mavondo, F. T., \& Saunders, S. G. (2018). The relationship between marketing agility and financial performance under different levels of market turbulence. Industrial Marketing Management. https://doi.org/10.1016/j.indmarman.2018.11. 008. 